\title{
Tectonic Studies in the Brazilian Shield
}

The Serra de Caldas Window, Goiás

Precambrian Plate Tectonics in the Brazilian Shield-

Evidence from the Pre-Minas Rocks

of the Quadrilátero Ferrífero, Minas Gerais

\section{GEOLOGICAL SURVEY PROFESSIONAL PAPER 1119-A,B}

Prepared in cooperation with the

Deparlamento Nacional de Aguas e Energia Eletrica, Departamento Nacional de Produção Mineral, and the

Companhia de Pesquisa de Recursos Minerais of Brazil

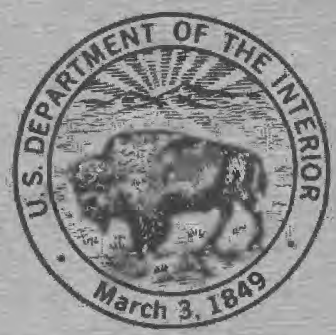




\title{
Tectonic Studies in the Brazilian Shield
}

\author{
The Serra de Galdas Window, Goiás
}

By Avery Ala Drake, Jr.

Precambrian Plate Tectonics in the Brazilian Shield-

Evidence from the Pre-Minas Rocks

of the Quadrilatero Ferrifero, Minas Gerais

By Avery Ala Drake, Jr., and Benjamin A. Morgan

GEOLOGICAL SURVEY PROFESSIONAL PAPER 1119 -A, B

Prepared in cooperation with the

Departamento Nacional de Aguas e Energia Eletrica, Departamento Nacional de Produção Mineral, and the

Companhia de Pesquisa de Recursos Minerais of Brazil

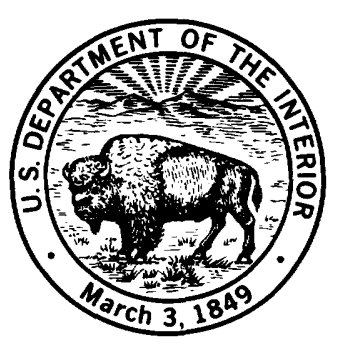

UNITED STATES GOVERNMENT PRINTING OFFICE, WASHINGTON : 1980 


\title{
UNITED STATES DEPARTMENT OF THE INTERIOR
}

\author{
CECIL D. ANDRUS, Secretary
}

GEOLOGICAL SURVEY

H. William Menard, Director

\section{Library of Congress Cataloging in Publication Data}

Main entry under title:

Tectonic studies in the Brazilian shield.

(Geological Survey professional paper ; 1119)

Includes bibliographical references.

CONTENTS: Drake, A. A., Jr. The Serra de Caldas window, Goiás.-Drake, A. A., and Morgan, B. A. Precambrian plate tectonics in the Brazilian shield.

1. Geology-Brazil-Goiás (State) 2. Geology, Stratigraphic-Pre-Cambrian. 3. Geology-Brazil-Quadilátero Ferrifero. I. Drake, Avery, Ala, Jr., 1927- The Serra de Caldas window, Goiás. 1979. II. Drake, Avery, Ala., Jr., 1927- Precambrian plate tectonics in the Brazilian shield. 1979. III. Morgan, Benjamin A. IV. Series: United States. Geological Survey. Professional paper ; 1119.

$\begin{array}{lll}\text { QE235.T42 } & 551.8^{\prime} 0981^{\prime} 7 & 78-31617\end{array}$

For sale by the Superintendent of Documents, U.S. Government Printing Office

Washington, D.C. 20402

Stock Number 024-001-03205-8 


\section{The Serra de Caldas Window, Goiás}

By Avery Ala Drake, Jr.

\section{TECTONIC STUDIES IN THE BRAZILIAN SHIELD}

GEOLOGICAL S URVEY PROFESSIONAL PAPER 1119-A

Prepared in cooperation with the

Departamento Nacional de Aquas e Energia Electrica,

Departamento Nacional de Produção Mineral, and the

Companhia de Pesquisa de Recursos Minerais of Brazil

Precambrian oceanic rocks, including ophiolitic

melánge, were obducted onto shelf deposits on the

west flank of the São Francisco craton during the

Eocambrian or earliest Paleozoic time







\section{CONTENTS}

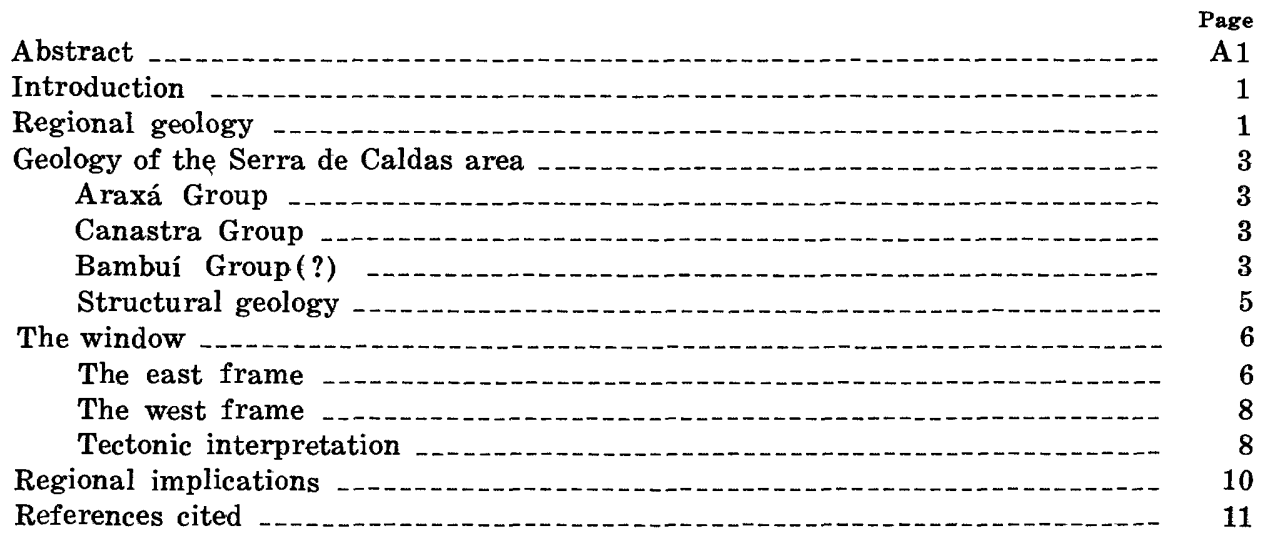

\section{ILLUSTRATIONS}

1. Generalized geologic map of part of Goiás and adjacent areas

2. Generalized geologic map of the Serra de Caldas area

3. Photographs of Araxá Group

4. Photographs of Bambuí Group (?)

5. Geologic map and sections, areas $A$ and B, east flank, Serra de Caldas _......... 7

6. Equal-area plots of small fold axes in rocks of the Bambuí(?) and Araxá Groups, east flank, Serra de Caldas - .

7,8. Geologic maps and sections, west flank, Serra de Caldas-

7. Areas $\mathrm{C}$ and $\mathrm{D}$

8. Areas $\mathrm{E}$ and $\mathrm{F}$

9. Equal-area plots of small fold axes in rocks of Bambuí, Canastra (?), and Araxá Groups, west flank, Serra de Caldas 


\title{
THE SERRA DE CALDAS WINDOW, GOIÁS
}

\author{
By Avery Ala Drake, Jr.
}

\begin{abstract}
The Serra de Caldas is a large topographic and structural high in southern Goiás. The Serra is underlain by shelf deposits of quartzite, siltstone, and lesser shale that have been weakly metamorphosed and deformed into upright concentric folds. These rocks are tentatively correlated with the Bambui Group of Eocambrian age.

The shelf deposits are surrounded on all sides by higher grade polyphase deformed schist and micaceous quartzite (quartz-grain turbidite) of the Araxá and Canastra Groups of Precambrian age. The Araxá contains abundant bodies of ultramafic and related mafic rocks, discontinuous bodies of marble, and blocks of quartzofeldspathic material and can be considered an ophiolitic mélange.

The contact between these different rocks suites is a tectonic and metamorphic discontinuity, marked by a zone of cataclastically deformed rock. These relations clearly show that the rocks are in fault contact and that the Serra is an antiformal window. Transport of the thrust sheet was probably from west to east, perhaps for a distance of as much as $200 \mathrm{~km}$.

The thrusting of ophiolitic mélange onto shelf deposits is of great importance because such occurrences commonly are the result of the obduction of oceanic rocks across a continental margin. The zone of thrusting described herein marks the western margin of the São Francisco craton. This obduction must date from the Eocambrian or earliest Paleozoic.
\end{abstract}

\section{INTRODUCTION}

The Serra de Caldas is a large topographic and structural dome or brachyanticline in southern Goiás about $130 \mathrm{~km}$ south-southeast of Goiânia, the capital of that State (fig. 1). The Serra and adjacent area served as a field-training area for a course in advanced geologic techniques for experienced geologists of the Companhia de Pesquisa de Recursos (CPRM) and the Departamento Nacional da Produção Mineral (DNPM). This course, given in the austral winter of 1973, was taught jointly by Professor V. J. Hurst of the University of Georgia and me. While doing reconnaissance in the area to prepare field-mapping exercises in advanced structural geology, I found evidence suggesting that the Serra de Caldas "dome" was a tectonic window. Subsequent detailed mapping by my students confirmed this idea. The purpose of this paper is to present the evidence for the window and to point out the regional implications of the structure.

I am indebted to my teaching colleague, V. J. Hurst, for field observations and for sharpening the talents of our students. Thanks are also due Hurst, as well as C. H. Thorman, Jr., of the U.S. Geological Survey for the photographs used herein, as I was plagued by the complete malfunction of two cameras during the course. Finally, I am in debt to my 22 students for their mapping and interest in this research. Special mention must be made of Lauri Bez, then of DNPM, and Gilberto Schudeller Pena, then of CPRM, for taking care of the logistical details during the course.

\section{REGIONAL GEOLOGY}

The area discussed herein is within the Araxá folded belt, which lies between the miogeoclinal deposits of the Paraguay-Araguria belt to the west and similar rocks of the Braziliano folded belt to the east (Almeida and others, 1973). This belt is underlain by the Araxá Group (Barbosa, 1955), a eugeosyclinal sequence of pelite, semipelite, psammite, and minor carbonate rock of 900-1,300-m.y. (million year) age (Brazil Dept. Nac. Produção Mineral, 1971). The Araxá contains much ultramafic and related mafic rock in both relatively small Alpine-type bodies and large complexes of gabbropyroxenite-peridotite (Berbert, 1970).

The Araxá is overlain to the east by the Canastra Group (Barbosa, 1955), which contains abundant quartzite interbedded with pelitic phyllite. This group has a flyschlike character and is considered to be 620-900 m.y. old (Brazil Dept. Nac. Produção Mineral, 1971). These rocks pass upward into 


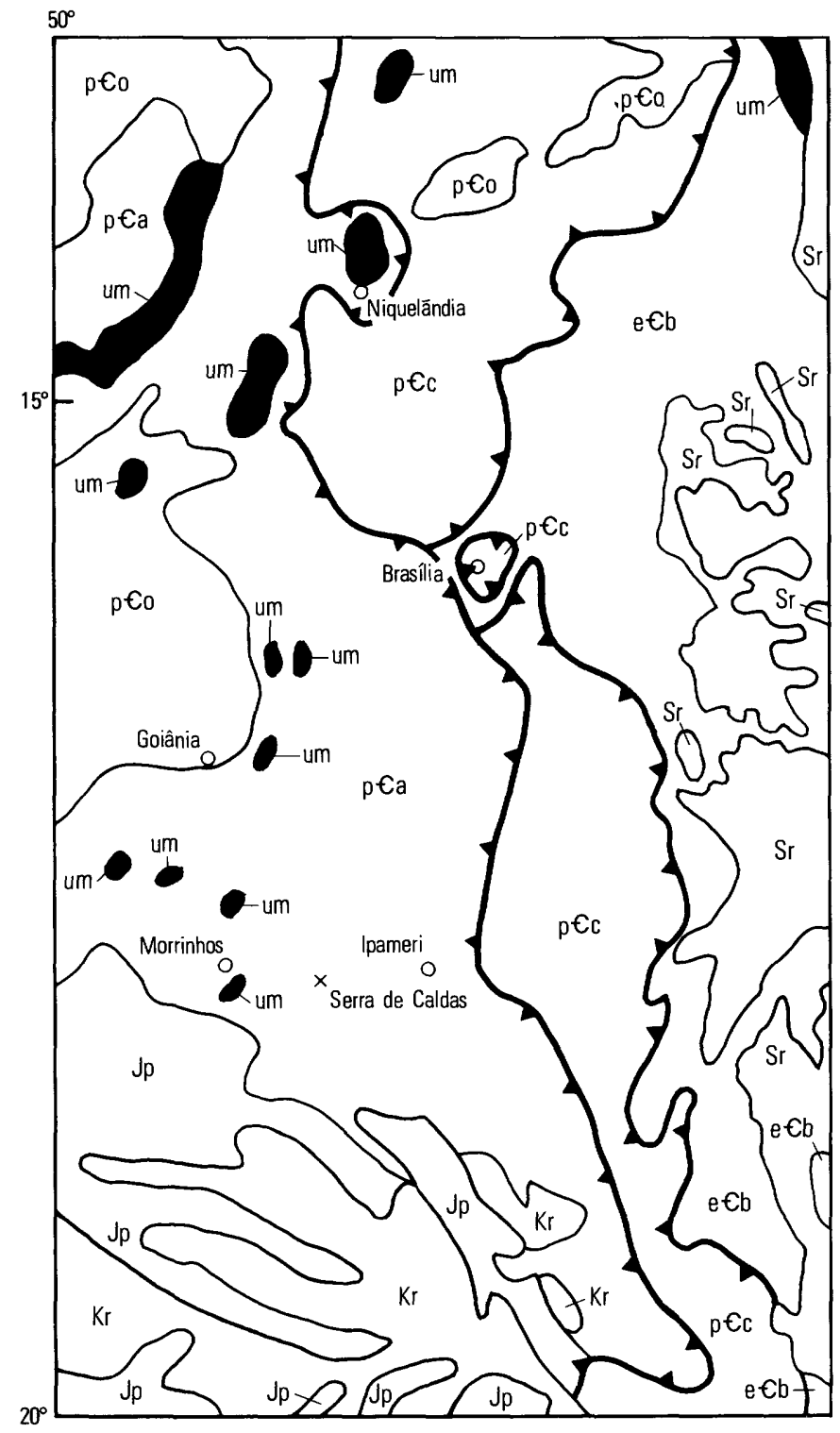

0

250 KLLOMETERS

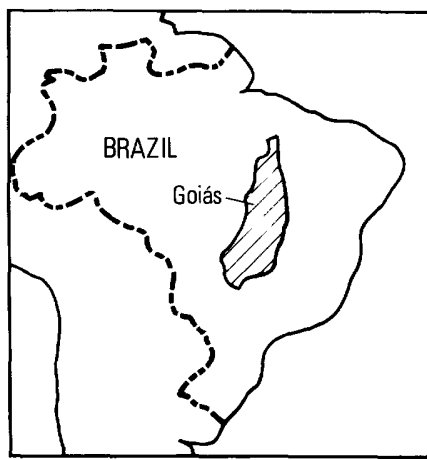

\section{EXPLANATION}

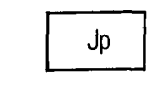

Parana Basalt

$\sqrt{\frac{0}{5}}$



了总

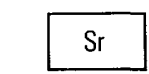

Sedimentary rocks

Bambuí Group

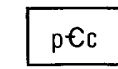

Canastra Group

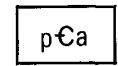

Araxá Group

$$
p \epsilon_{0}
$$

Older, granulite facies rocks
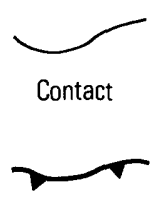

Thrust fault

Sawteeth on upper plate
Ultramafic and associated rocks. Includes Alpine-type material in Araxá ophiolitic mélange as well as larger bodies of possible different age 
the molasse and shelf deposits of the Bambui Group of Eocambrian age (Brazil Dept. Nac. Produção Mineral, 1971).

The rocks of the Araxá folded belt have a strong tectonic vergence toward the São Francisco platform to the east (Ferreira, 1972). Rocks of the Araxá Group have been thrust over both the Canastra and Bambui Groups, and Canastra rocks have been thrust over rocks of the Bambuí Group (fig. 1), marking strong west-to-east tectonic transport during the Eocambrian or earliest Paleozoic.

\section{GEOLOGY OF THE SERRA DE CALDAS AREA}

The geology of the Serra de Caldas area is known mostly from the work of Braun (1970b). Three rock sequences can be recognized-the Araxá Group, the Canastra Group, and a sequence of quartzite, siltstone, and lesser shale that can probably be correlated with the Bambui Group (fig. 2). These rocks form an extremely complex tectonic terrane, evident even at the small scale of figure 2. Structural studies have been, and will continue to be, hindered by the generally poor exposure, deep weathering, and complicated stratigraphy.

\section{ARAXÁ GROUP}

In the Serra de Caldas area, the Araxa Group was divided into three units by Braun $(1970 \mathrm{~b})$. The lowermost unit consists primarily of muscovite-biotite-plagioclase-quartz schist that contains some intercalations of micaceous quartzite. The unit is in amphibolite facies (Braun, 1970b) and at several places is a gneiss.

The middle unit is more psammitic, consisting of interbedded quartzite (quartz sand turbidites) and muscovite-quartz schist. Bedding in this unit is transposed, and the primary planar element is flow cleavage.

The upper unit of the Araxá is the most important to this study because it surrounds the Serra de Caldas. It is quite pelitic, the most common rock type being muscovite-biotite-plagioclase-quartz schist, although garnet-chlorite-biotite-quartz schist is fairly abundant. The unit was metamorphosed to at least high greenschist facies, but at places it contains megascopic kyanite and andalusite, suggesting higher rank metamorphism.

The upper Araxá contains numerous small bodies of ultramafic and related mafic rock in the form of serpentinite, actinolite schist (probably metapyroxenite), talc schist, and chlorite schist (Braun, 1970a). These bodies are far more abundant than those shown in figure 2 because most are too small to show at that scale. This part of the Araxá, then, can be considered an ophilitic mélange in the sense of Gansser (1974) and Williams (1977).

The mélangelike nature of the upper unit is further documented by many discontinuous bodies of marble (Braun, 1970b), which are probably exotic blocks within this complex schist terrane. In addition, polymictic mélange has been noted elsewhere within the upper part of the Araxá (fig. $3 A$ ).

Bedding is completely transposed within this unit, and transposition foliation is the principal planar element. Most exposures are characterized by disrupted fold hinges swimming like tectonic fish within a sea of pelite (fig. $3 B$ ). In many places, the transposition foliation is transposed, and strain-slip foliation is the dominant planar feature.

\section{CANASTRA GROUP}

The Araxá passes up into a sequence of quartzite, quartz-rich phyllite, and pelitic schist that have been assigned to the Canastra Group by Braun (1970b). The pelitic parts of the unit consist of muscovitebiotite-quartz schist and a quite alumina- and ironrich interval characterized by chloritoid-muscovitequartz schist. The Canastra, though strongly deformed, is less so than the Araxá, and bedding can be seen in many exposures. The unit is at biotite grade of regional metamorphism.

\section{BAMBUí GROUP(?)}

A sequence of orthoquartzite and slitstone containing interbeds of shale underlies the Serra de Caldas. The quartzite, which is quite pure, forms beds a meter or more thick and is responsible for the topographic expression of the Serra. This rock is overlain by quartz siltstone and interbedded shale. The shale has been called phyllite, but, although at chlorite grade, it lacks a penetrative foliation. Bedding is the principal parting surface and is well preserved in most exposures, as are other primary sedimentary structures such as ripple marks (fig. $4 A$ ), crossbeds, convolute folds, and sedimentary boudinage. In addition, probable grazing trails on bedding surfaces are only slightly deformed, if at all (fig. $4 B)$.

These rocks were once confused with the middle unit of the Araxá Group because of their quartzose nature and their position beneath the upper part of the Araxá. Clearly, however, these rocks, probably deposited in a transitional (continental marine) environment, have nothing in common with the deep marine rocks of the middle part of the Araxá. The 


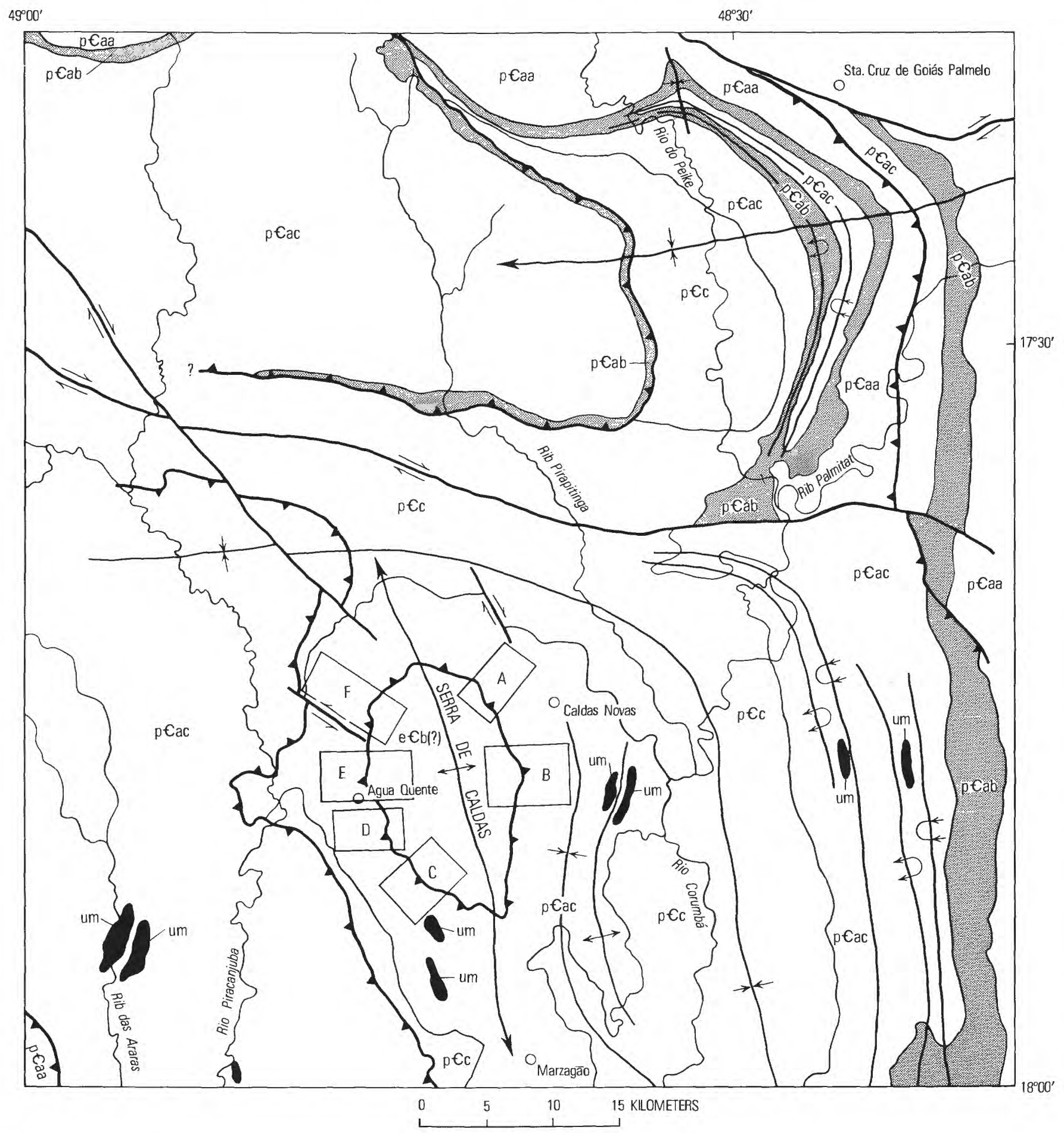

FIGURE 2.-Generalized geologic map of the Serra de Caldas area (modified from an unpublished map by O. P. G. Braun, 1968). Areas $A$ and $B$ are enlarged in figure 5 , areas $C$ and $D$ in figure 7 , and areas $E$ and $F$ in figure 8.

lack of a tectonic fabric is also strong evidence that these rocks cannot be Araxá Group. It seems inescapable then that the quartzite-siltstone sequence contact with the Araxá rocks is tectonic, not sedimentary.
The only rocks known in Goiás that resemble those underlying the Serra de Caldas are in the Bambuí Group. In the Brasilia area, Dyer (1970) described a sequence of quartzite, siltstone, and "slaty phyllites" at the base of the Bambuí Group. 
EXPLANATION

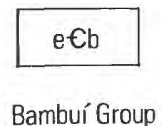

Bambuí Group (?)

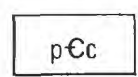

Canastra Group

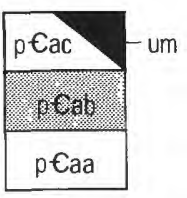

Araxá Group

p Cac, upper unit; um, ultramafic and related rocks $p € a b$, middle unit; $p €$ Caa, lower unit

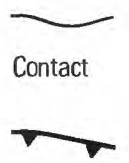

Thrust fault

Sawteeth on upper plate

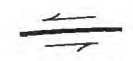

Wrench fault

Showing relative horizontal movement

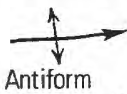

Showing direction of plunge

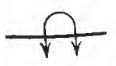

Overturned antiform

Showing direction of dip of limbs

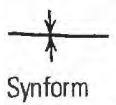

Showing direction of plunge

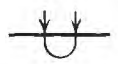

Overturned synform

Showing direction of dip of limbs

Figure 2.-Continued.

These rocks are predominantly sandy and are assigned to the Paranoa Formation. The description of these rocks is perfect for the rocks at the Serra de Caldas, which, therefore, are tentatively correlated with the Bambuí Group.

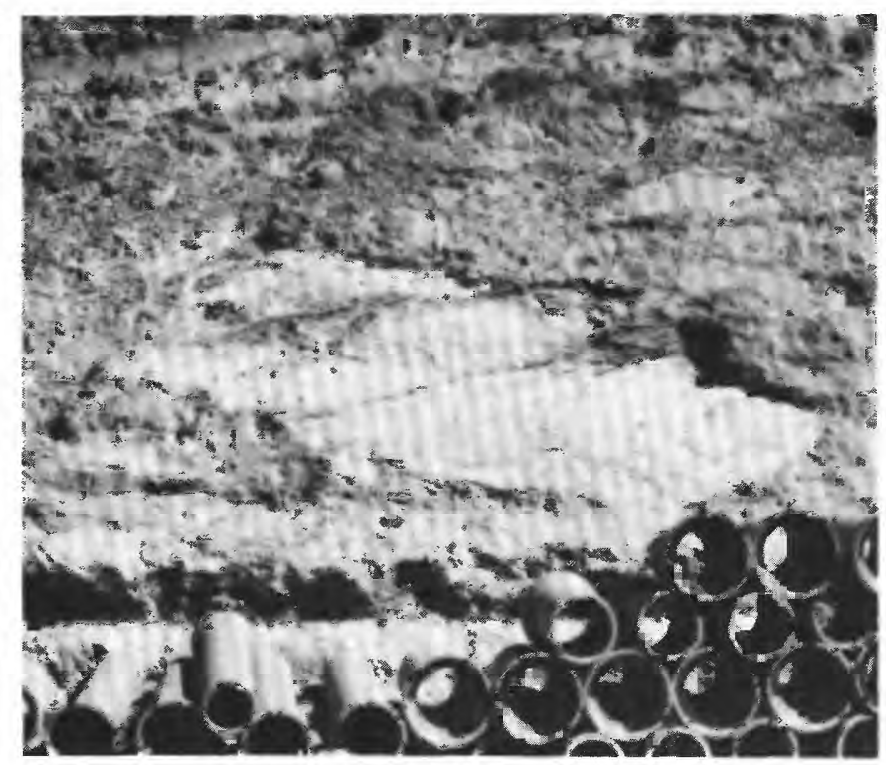

A

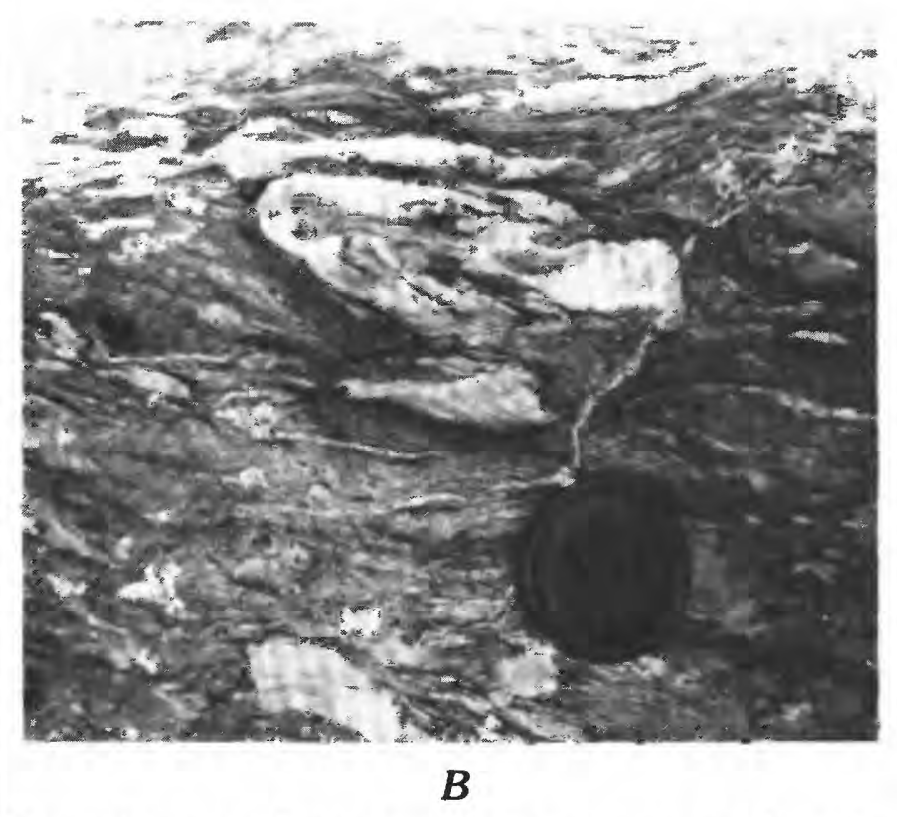

Figure 3.-Araxá Group. $A$, Saprolite exposure of polymictic mélange. $B$, Polyphase deformed schist. Photographs by C. H. Thorman, Jr.

\section{STRUCTURAL GEOLOGY}

Only a casual glance at figure 2 is needed to note the extreme structural complexity of the Serra de Caldas area. Strong west-to-east transport is shown by the overturned folds and imbricate thrust faults, which are also folded. Large type 1 and type 2 fold interference patterns (Ramsay, 1967) are immediately identifiable. Type 3 patterns are not apparent at the scale of figure 2 , but such interference struc- 


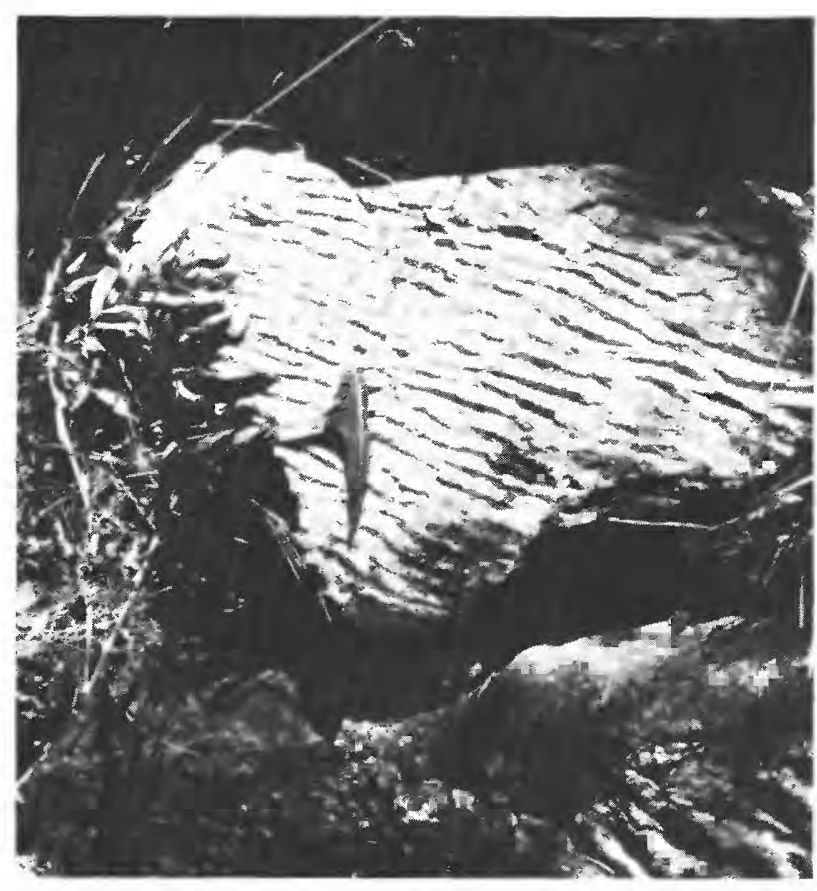

A

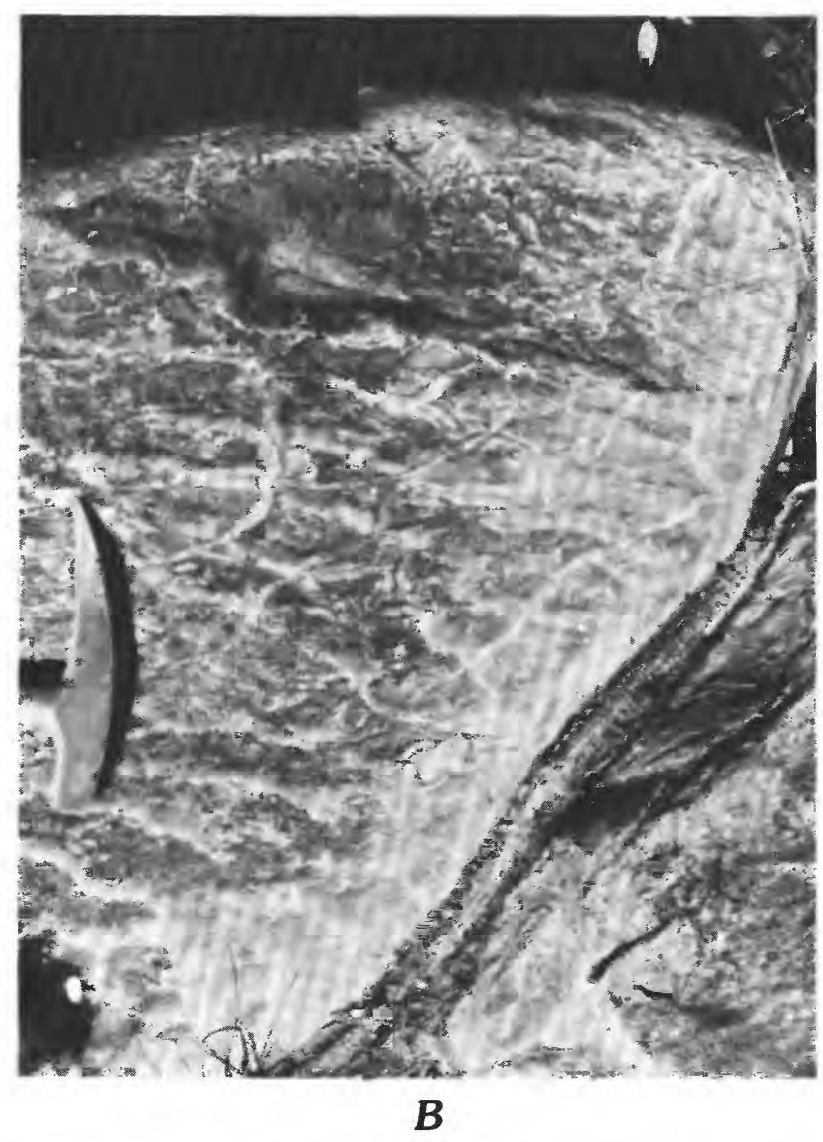

Figure 4.-Bambuí Group(?) $A$, Ripple-marked quartzite. $B$, Grazing trails(?) on bedding surface. Photographs by V. J. Hurst. tures are abundant in outcrop (fig. $3 B$ ). At many places, the Araxá rocks have three sets of coaxial folds. The axes of early recumbent folds have been recumbently folded, and both of these axes have been deformed by steep, more or less symmetric folds. The axes of these three sets of folds have been folded by a later oblique set.

Two sets of wrench faults have been mapped (fig. 2 ). The large east-trending fault is probably a tear related to the east-directed thrusting. The northwest-trending faults result from later deformation, but I have no specific data with which to interpret them.

\section{THE WINDOW}

During reconnaissance in the Serra de Caldas area, I discovered a marked difference in tectonic style between the rocks surrounding the Serra and those within it. In addition, cataclastically deformed rock was found at the contact of the Araxá and Bambuí rocks at one place. It seemed likely that the Serra was a window. To test this hypothesis, students were assigned areas in which to make detailed strip maps. This mapping was done on aerial photographs at a scale of $1: 60,000$, as there are no topographic maps of the area. Six of these maps (outlines, shown on fig. 2) are presented here as part of the evidence for the window.

\section{THE EAST FRAME}

Figure 5 shows geologic maps of areas A and B on the east flank of the Serra de Caldas. In both areas, rocks of the Bambuí Group(?) are separated from more complexly deformed rocks at higher metamorphic grade by a zone of cataclastic deformed rock that dips gently to the east. In area A (fig. 5), the Bambui Group(?) is in fault contact with interbedded micaceous quartzite and schist like those of the Canastra Group. The quartzite and schist are correlated with the Canastra Group though they could conceivably be interbedded in the Araxá. Small, mostly upright, concentric folds in the Bambuí Group(?) plunge gently west of north (fig. $6)$, although folds in the southern part of area $B$ (fig. 5) plunge east of south, reflecting the doubly plunging nature of the Serra de Caldas brachyanticline. Late small folds in the Araxá Group (fig. 6) about parallel those in Bambuí(?). Most of the early folds plunge either southeast or northwest (fig. 6), depending on their location on the limb of a late synform (area B, fig. 5). These folds are in both transportation foliation and second-generation strain-slip foliation and are characteristically flattened similar 
Area A

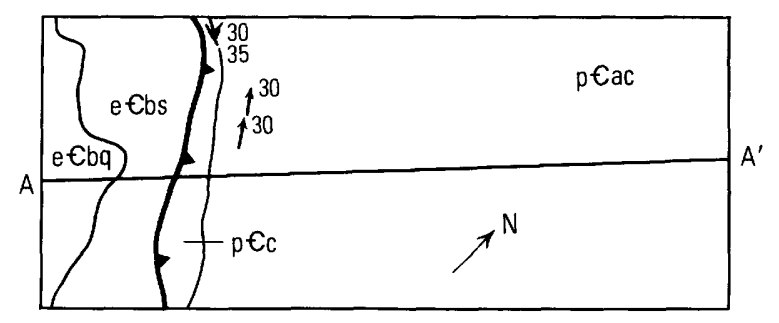

$0 \quad 600 \quad 1200$ METERS

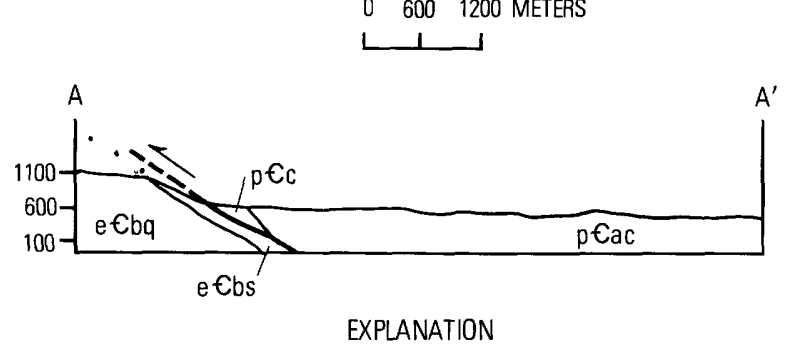

Bambuí Group (?)

e€bs, siltstone; e bq, quartzite



Canastra Group

$$
p € a c
$$

Araxá Group, upper unit

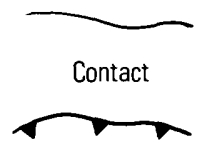

Thrust fault

Sawteeth on upper plate



Showing trace of axial surface and direction

of dip of limbs and plunge

Area B

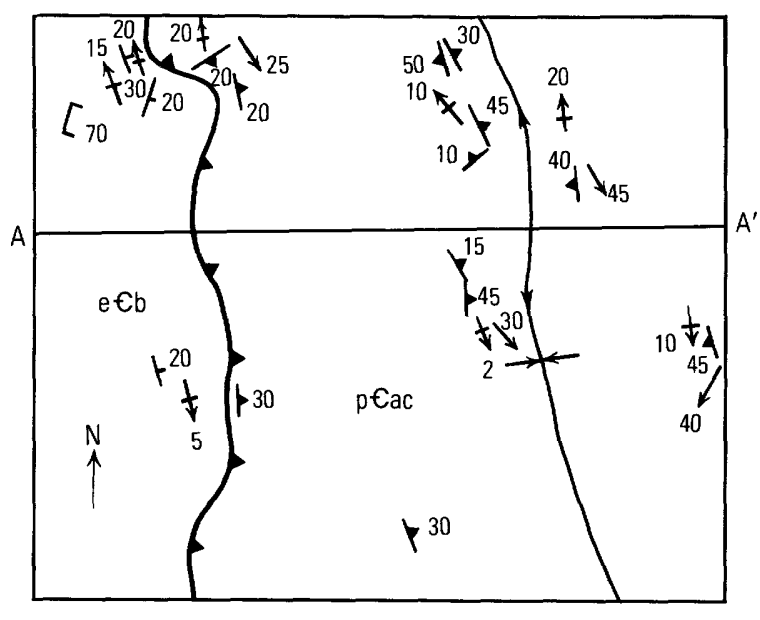

$0 \quad 600 \quad 1200$ METERS

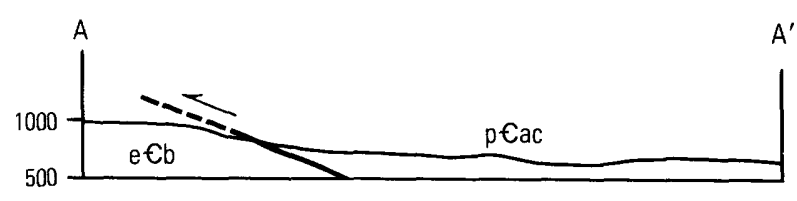

$\overbrace{20}$

Strike and dip of beds

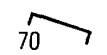

Strike and dip of cleavage

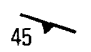

Strike and dip of foliation
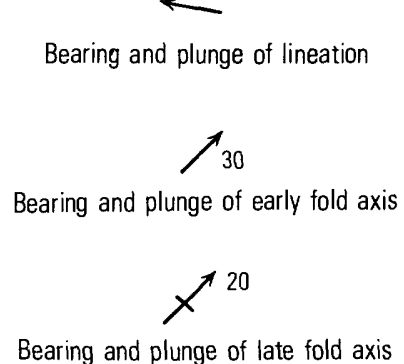

Figure 5.-Geologic maps and sections of areas A and B (fig. 2). Geology by H. de O. Godoi and J. T. Takanohashi.

folds. Few first folds can be seen, and their axes are virtually impossible to measure. On the east flank of the Serra, the obvious late folds, those in which the strain-slip foliation defines the form surface, parallel those in the Bambuí(?) rocks. These folds have a spaced axial surface cleavage that parallels the cleavage in younger rocks. Clearly, the late fabric in the older rocks is the same as the fabric in the younger rocks. 

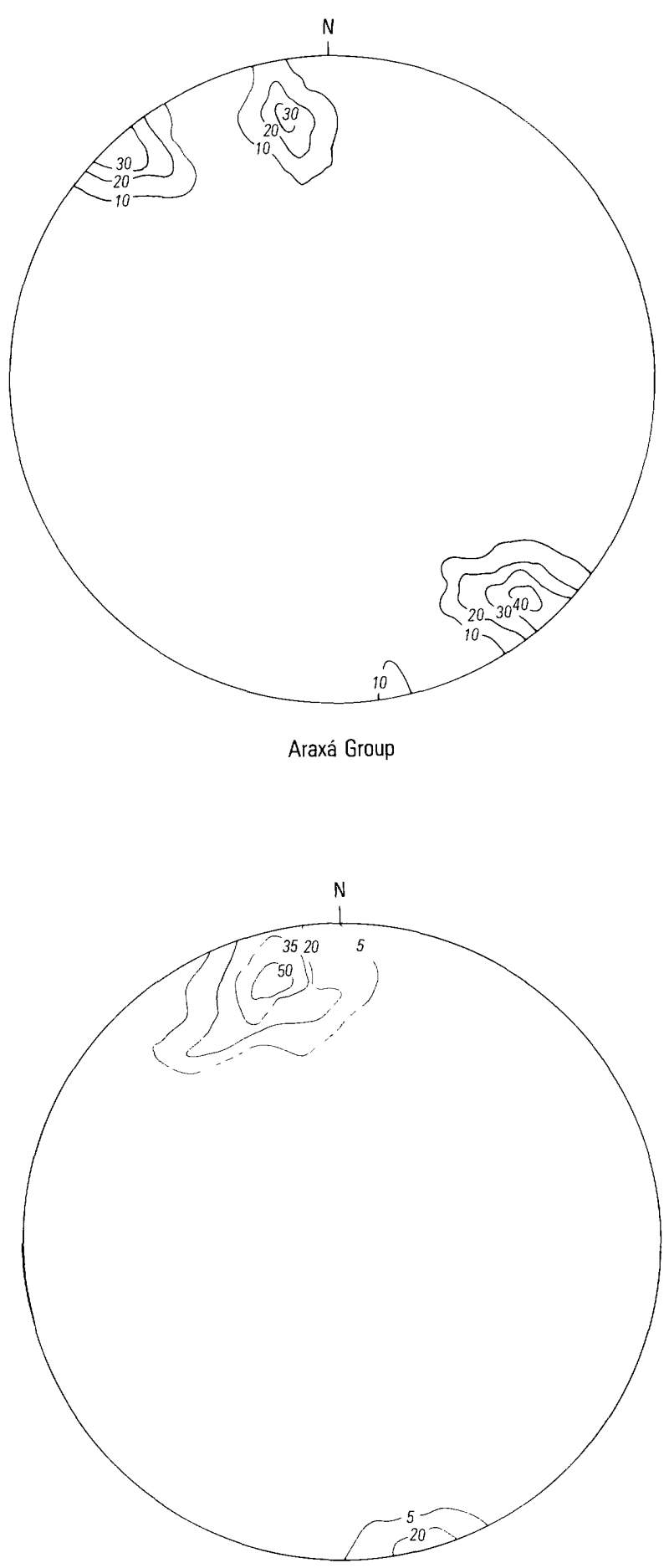

Bambuí Group (?)

Figure 6.-Equal-area plots of 32 small fold axes in rocks of the Bambui Group(?) and of 65 small fold axes in rocks of the Araxá Group on the east flank of the Serra de Caldas. Contours at 5, 20, 35, and 50 percent per 1 percent area for the Bambui Group and at $10,20,30$, and 40 percent per 1 percent area for the Araxá Group.

\section{THE WEST FRAME}

Figures 7 and 8 are geologic maps of areas C-F on the west flank of the Serra de Caldas. On this flank as well, a zone of cataclastically deformed rocks separates the Bambui Group(?) from the older polyphase terrane. In areas $E$ and $F$ (fig. 8), interbedded micaceous quartzite and schist like those of the Canastra Group lie between rocks of the Araxá Group and the thrust fault. Rocks of the Canastra Group crop out in the northwesternmost corner of area $F$ (fig. 8) in a synform. It seems likely, therefore, that the micaceous quartz schist adjacent to the thrust fault shown in area $\mathrm{A}$ (fig. 5) and areas $E$ and $F$ (fig. 8) is Canastra folded into the Araxá.

Axes of small folds in bedding in rocks of the Bambuí Group (?) plunge gently north-northwest (fig. 9), whereas those in bedding in the Canastra Group (?) plunge both west-northwest and northnorthwest. The late folds, those that plunge northnorthwest, also fold the schistosity in the Canastra (?) rocks.

Three sets of folds can be recognized in rocks of the Araxá Group (fig. 9). All three sets fold the transposition foliation, and the second-generation strain-slip foliation is folded by both the west-northwest- and north-northwest-plunging sets. First folds are difficult to find and impossible to measure. The earliest west-plunging folds are characteristically flattened similar folds. Many are so severely flattened that opposite limbs are completely appressed, and no hinge zone can be recognized. The westnorthwest-plunging folds are characteristically similar, whereas the late north-northwest-plunging folds are concentric and have a spaced axial surface cleavage that parallels the cleavage in the Bambui rocks. On this flank as well, the late fabric in the older rocks parallels the fabric in the Bambuí(?) rocks, and earlier fabrics have been folded over the Serra de Caldas.

\section{TECTONIC INTERPRETATION}

Fieldwork has shown that a low-grade sequence of quartzite, siltstone, and lesser shale is surrounded by high-grade polyphase deformed rocks. This tectonic and metamorphic discontinuity is everywhere marked by a zone of cataclastically deformed rock. The Serra de Caldas, then, is a large antiformal window, about $250 \mathrm{~km}^{2}$ in extent, trending just west of north. Rocks of the Araxá and Canastra Groups were metamorphosed and deformed prior to their emplacement, as shown by the folded early foliations 
Area C
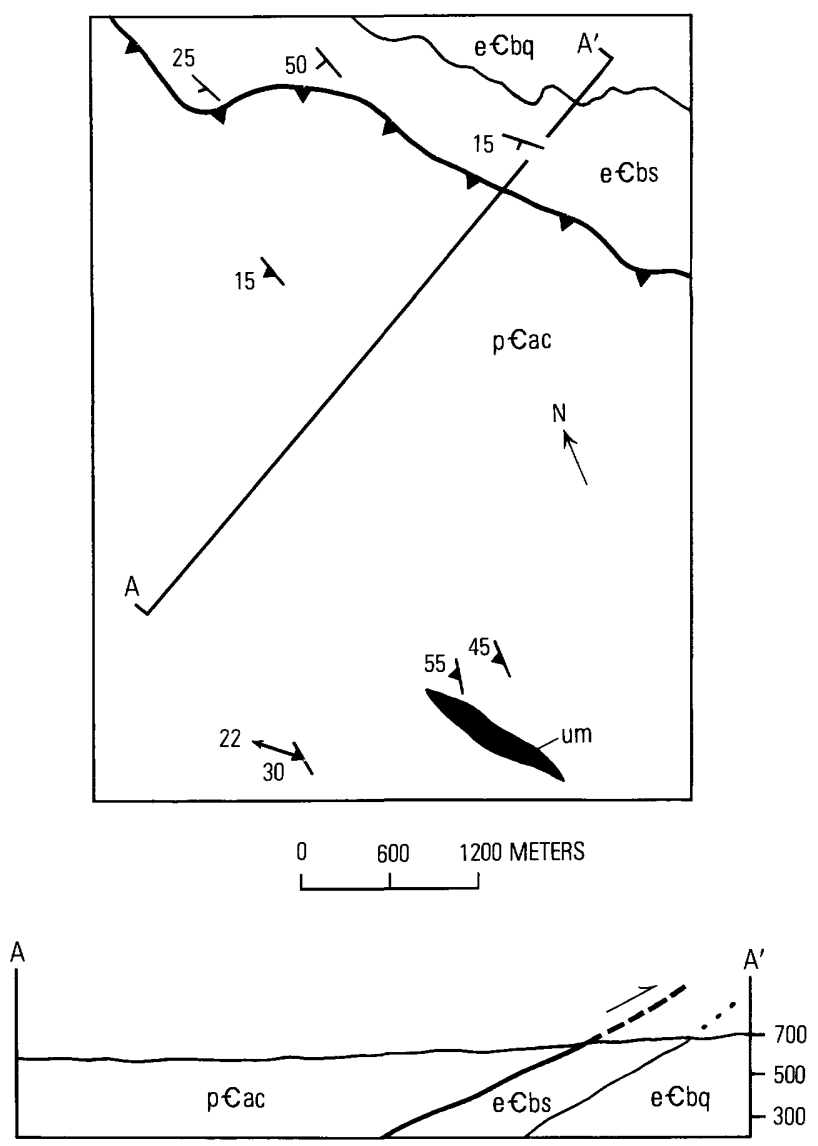

EXPLANATION

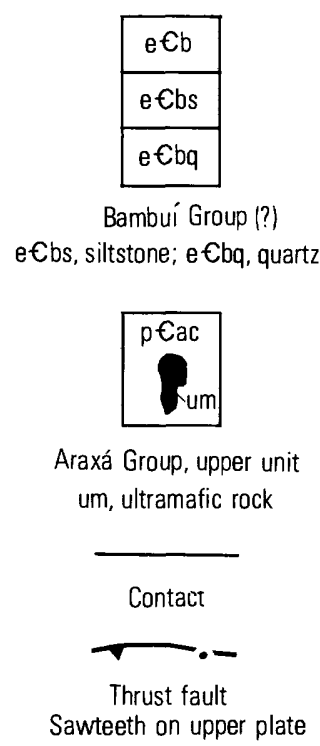

Area D
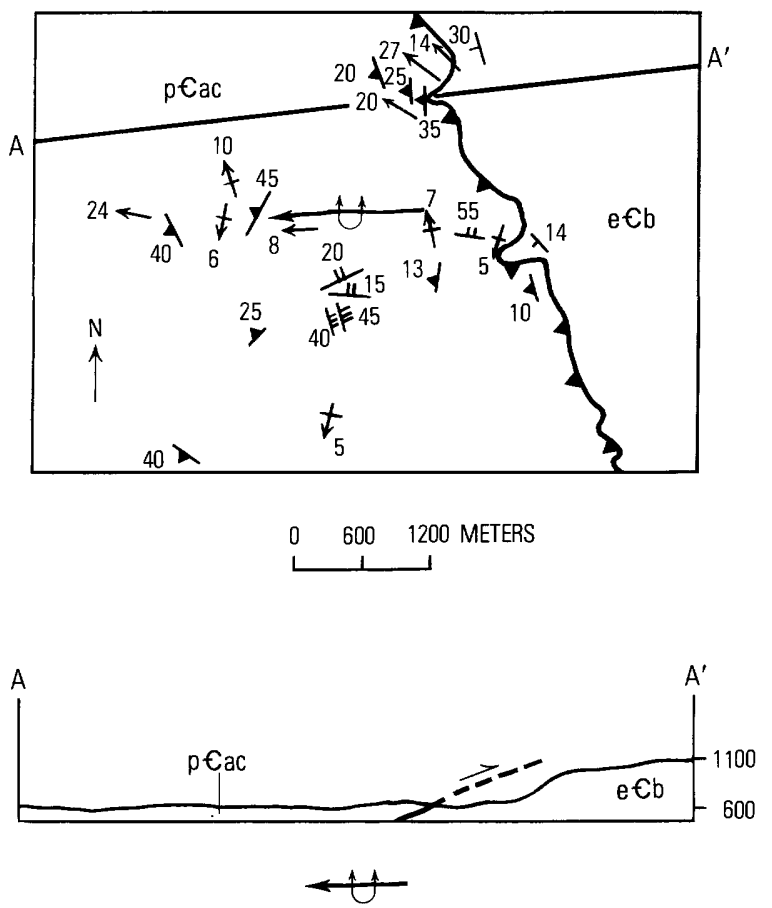

Antiform

Showing trace of axial surface and direction of plunge and dip of limbs

$$
30,
$$

Strike and dip of beds

10,

Strike and dip of first foliation

45 _

Strike and dip of second foliation $20 \mathrm{~m}$

Strike and dip of third foliation<smiles>CC[14CH3]</smiles>

Bearing and plunge of early lineation

$10 \leftarrow$

Bearing and plunge of late lineation

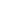

Figure 7.-Geologic maps and sections of areas C and D (fig. 2). Geology by G. S. Pena, Paulo Frassinette, and M. M. Sugahara. 
Area $\mathrm{E}$


EXPLANATION

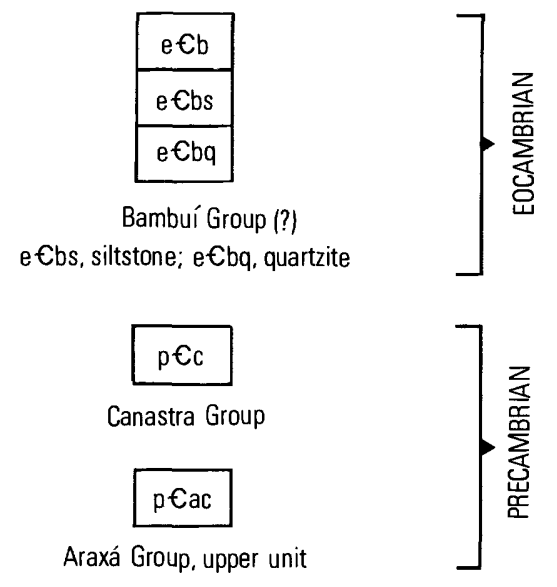

Figure 8.-Geologic maps and sections of areas $E$ and $F$

in these rocks and by the low rank of metamorphism in the Bambuí(?) rocks. Regional relations (figs. 1 and 2) suggest that thrusting was directed nearly due east, but that suggestion has not been proved. The amount of transport is difficult if not impossible to determine. The main outcrop belt of Bambuí rock is about $200 \mathrm{~km}$ east of the Serra de Caldas. Unless an area of Bambuí rock in normal stratigraphic position is present west of that shown on the part of the geologic map of Brazil shown in figure 1,
Area $F$

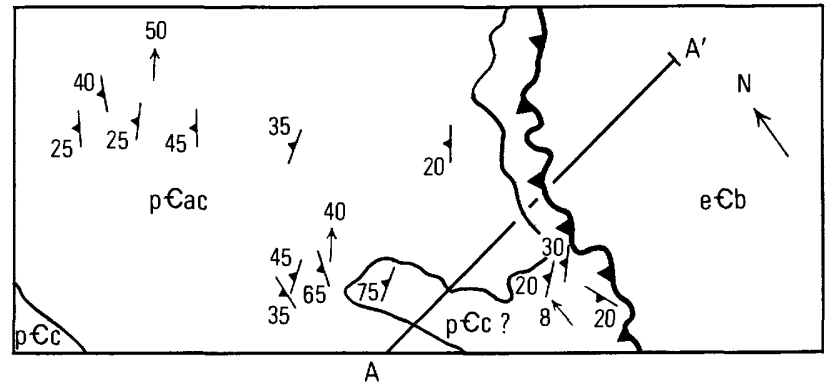

$0 \quad 6001200$ METERS
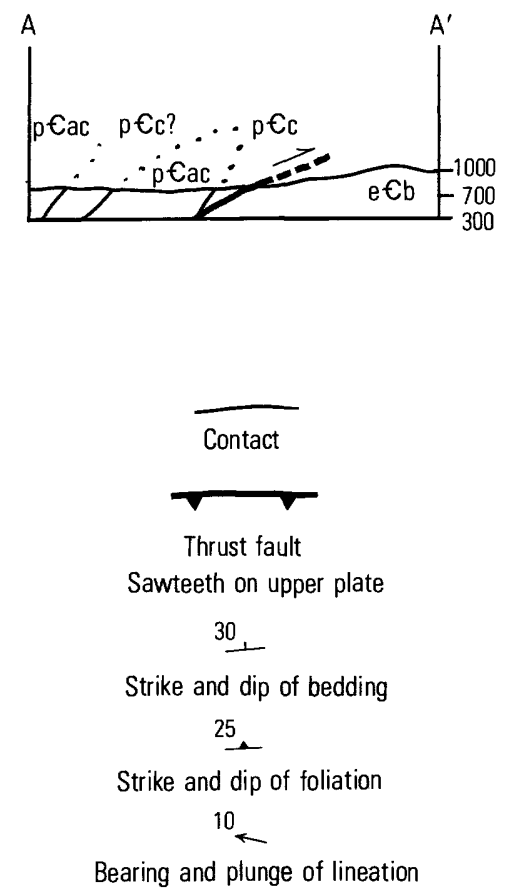

(fig. 2). Geology by Amilcar Adamy and Lauri Bez.

transport of about $200 \mathrm{~km}$ is required. I should point out that rocks of the Canastra Group crop out in the Serra de Caldas area (fig. 2) that were not shown in figure 1; areas of unrecognized Bambuí may also exist.

\section{REGIONAL IMPLICATIONS}

Shelf-facies rocks of Bambuí aspect occur in a window beneath transported deep marine sediments, 

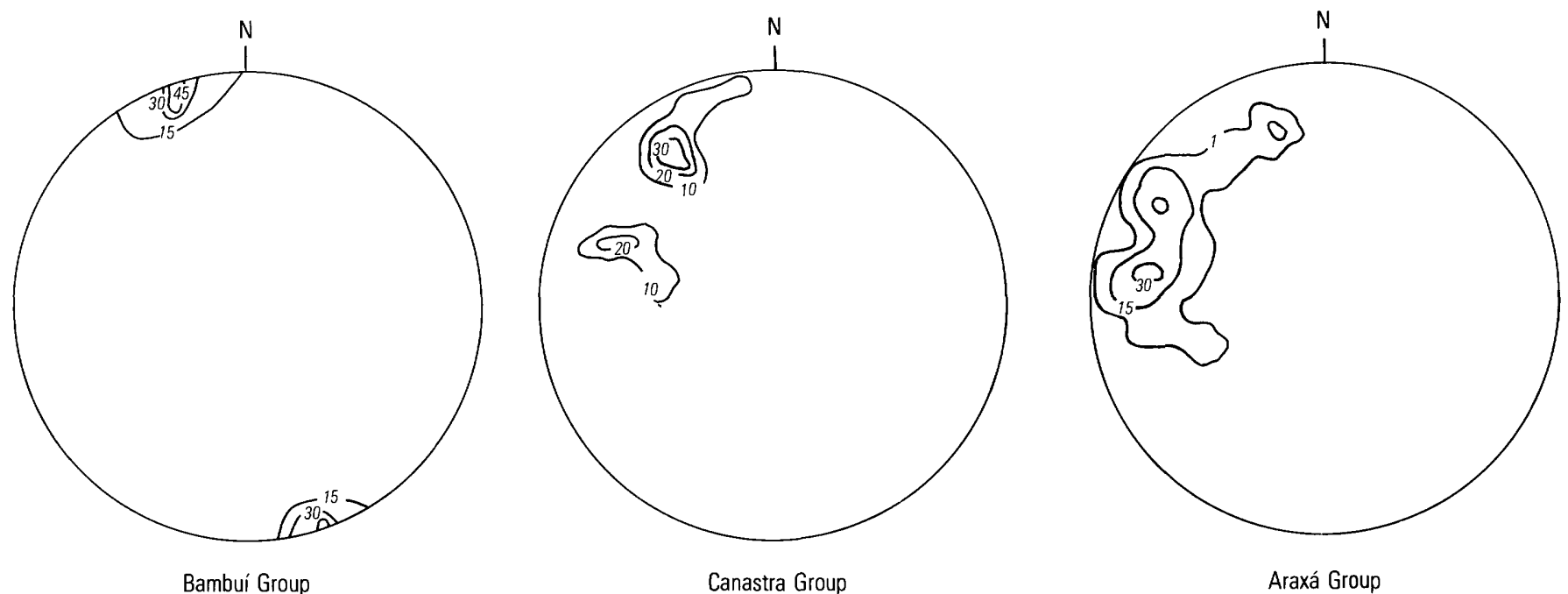

FigUre 9.-Equal-area plots of 42 small fold axes in rocks of the Bambuí Group, 30 in rocks of the Canastra Group(?), and 60 in rocks of the Araxá Group-all on the west flank of the Serra de Caldas. Contours at 15, 30, and 45 percent per 1 percent area for the Bambuí Group; at 10, 20, and 30 percent per 1 percent area for the Canastra Group; and at 1,15 , and 30 percent per 1 percent area for the A raxá Group.

which are, in part, an ophiolitic mélange. Such rocks are of extreme importance, as throughout the world they commonly mark the boundaries of suture zones (Coleman and Irwin, 1974), which in most places are destroyed continental margins (Williams, 1977). Most known examples are the result of obduction, that is, the overthrusting of oceanic rocks across continental margins (Gansser, 1974). As prePaleozoic occurrences are rare, this Brazilian example is important.

In most areas of ophiolitic mélange, such as Newfoundland, Oman, Urals, Himalayas, and Zagros, the mélange is overlain by an ophiolite sheet, the mélange resulting from the mass wasting of the advancing nappe. I would like to suggest, therefore, that some of the larger bodies of ultramafic and related rock in the area mapped, such as those at and southwest of Niquelandia (fig. 1), may be ophiolite nappes and may have a much more complex origin than is commonly believed. In any case, oceanic material has been thrust upon cratonic shelf deposits, transport perhaps being as great as $200 \mathrm{~km}$ during the Eocambrian or earliest Paleozoic.

\section{REFERENCES CITED}

Almeida, F. F. M. de, Amaral, G., Cordani, U. G., and Kawashita, K., 1973, The Precambrian evolution of the South America cratonic margin south of the Amazon River, in Nairn, A. E. M., and Stehli, F. G., eds., The ocean basins and margins, v. 1, The South Atlantic: New York, Plenum Press, p. 411-446.
Barbosa, Octavio, 1955, Guia das excursoes do IX Congresso da Socidade Brasileira de Geologia: Soc. Brasileira Geologia Noticiario 3.

Berbert, C. O., 1970, General geology of the basic-ultrabasic complexes of Goiás: Cong. Brasileiro Geologia, 24th, Brasilia, 1970, Bol. Especial 1, p. 24-28.

Braun, O. P. G., 1970a, The economic significance of the Caldas Novas greenschist: Cong. Brasileiro Geologia, 24th, Brasilia, 1970, Bol. Especial 1, p. 134-135.

- 1970b, Geologia da area de Caldas Novas, Ipamerie Arredores, no Estado de Goiás: Cong. Brasileiro Geologia, 24th, Brasilia, 1970, Bol. Especial 1, p. 205-207.

Brazil Departmento Nacional da Produção Mineral, 1971, Mapa geologico do Brasil: Rio de Janeiro, scale $1: 5000000$.

Coleman, R. G., and Irwin, W. P., 1974, Ophiolites and ancient continental margins, in Burk, C. A., and Drake, C. L., eds., The geology of continental margins: New York, Springer-Verlag, p. 921-931.

Dyer, R. C., 1970, Apresentacão preliminar da geologia da folha "Brasilia": Cong. Brasileiro Geologia, 24th, Brasilia, 1970, Bol. Especial 1, p. 214-216.

Ferreira, E. O., 1972, Carta tectonica do Brasil [Tectonic map of Brazil] : Brazil Dept. Nac. Produção Mineral Bol. 1, 19 p. (Portuguese), 14 p. (English), col. geol. map, scale 1: 5000000 .

Gansser, Augusto, 1974, The ophiolitic melange, a world-wide problem on Tethyan examples: Eclogae Geol. Helvetiae, v. 67 , no. 3 , p. $479-507$.

Ramsay, J. G., 1967, Folding and fracturing of rocks: New York, McGraw-Hill, 568 p.

Williams, Harold, 1977, Ophiolitic melange and its significance in the Fleur de Lys Supergroup, northern Appalachians: Canadian Jour. Earth Sci., v. 14, no. 5, p. 987-1003. 



\section{Precambrian Plate Tectonics in the Brazilian Shield-Evidence from the Pre-Minas Rocks of the Quadrilátero Ferrífero, Minas Gerais}

By Avery Ala Drake, Jr., and Benjamin A. Morgan

\section{TECTONIC STUDIES IN THE BRAZILIAN SHIELD}

GEOLOGICAL SURVEY PROFESSIONAL PAPER 1119-B

Prepared in cooperation with the

Departamento Nacional de Aguas e Energia Electrica,

Departamento Nacional de Produção Mineral, and the

Companhia de Pesquisa de Recursos Minerais of Brazil

Oceanic rocks, including ultramafic and mafic rocks

that are parts of a disrupted ophiolite assemblage,

were obducted onto the east flank of the granitoid

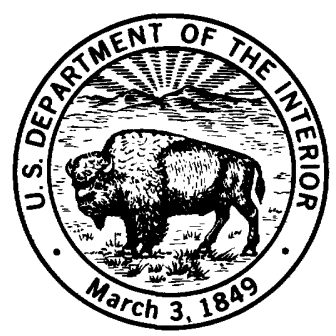

São Francisco craton during Archean time 



\section{CONTENTS}

Abstract
Introduction
Acknowledgments
The granitoid craton $\mathrm{Tio}$ das Velhas Series
Conclusion
References cited

\section{ILLUSTRATIONS}

1. Stratigraphic section in the Quadrilátero Ferrifero, Minas Gerais

2. Generalized geologic map of the Quadrilátero Ferrífero

3. Photomicrographs of cataclastic granitoid rocks, Quadrilátero Ferrífero -

4. Photographs of polyphase folds in the granitoid terrane along the north front of the Quadrilátero Ferrifero -

5. Diagram showing $\mathrm{Al}_{2} \mathrm{O}_{3}-\mathrm{MgO}-\mathrm{FeO}-\mathrm{K}_{2} \mathrm{O}$ projection for mineral assemblages for the staurolite schist

6. Photographs of schists from the Quadrilátero Ferrífero.

7. Photographs showing unconformable contact between staurolite-garnet schist and Moeda Quartzite on southeast flank of Bação dome -

8. Geologic map showing distribution of ultramafic and mafic rocks in the Rio Acima and Macacos quadrangles

(1)

\section{TABLES}

1. Summary of isotopic age dates for the Bação and Bonfim Complexes, Quadrilátero Ferrífero, Minas

Gerais -

2. Comparison of the chemistry of gneiss with graywacke, pelite, and calcareous phyllite of the Nova Lima Group -..............

3. Chemical analyses and normative minerals of gabbro and ultramafic rocks, Quadrilátero Ferrífero 



\title{
PRECAMBRIAN PLATE TECTONICS IN THE BRAZILIAN SHIELD- EVIDENCE FROM THE PRE-MINAS ROCKS OF THE QUADRILÁTERO FERRÍFERO, MINAS GERAIS
}

\author{
By Avery Ala Drake, Jr., and Benjamin A. Morgan
}

\begin{abstract}
The Precambrian pre-Minas rocks of the Quadrilátero Ferrifero in Minas Gerais were restudied and reinterpreted using a simplified plate-tectonic model. The principal elements of this interpretation are as follows: (1) Many of the granitoid rocks and gneisses of the area are part of an ancient cratonic massif (the São Francisco craton) and are not later intrusions into metasedimentary and metavolcanic rocks of the region. (2) The cratonic rocks are overthrust by a sequence of flyschoid rocks of the Nova Lima Group. This sequence includes ultramafic and related mafic rocks that are parts of a disrupted ophiolite assemblage. Metamorphic muscovite from the cratonic basement and from schists of the Nova Lima Group has an age of 2.6 or 2.7 b.y.; therefore, the allochthon was in place by that time. The Nova Lima allochthon, which includes this ophiolitic material, is therefore a very early example of plate tectonics, and was obducted perhaps from the southeast onto the São Francisco craton during Archean time.

After emplacement of the allochthon, rocks of the Minas and Itacolomi Series were deposited. The style of deformation and the pattern of distribution of rock units are largely the result of later major orogeny in the Quadrilatero. During this orogeny, the basement was remobilized and deformed upward, producing gneiss domes. The allochthon and later sedimentary sequences were deformed into tight, pinched-in polyoriented synclines surrounding the domes.
\end{abstract}

\section{INTRODUCTION}

"The picture of the Atltantic Ocean segment crowding the eastern side of the South American Continent, squeezing it and forcing it upwards like a triangular wedge and slicing the edge comes very appealingly to mind" (Harder and Chamberlin, 1915, p. 370).

The concept of plate tectonics seems well established for the Phanerozoic Eon; however, extrapolation of this concept backward in time into the Precambrian involves much uncertainty. Many stu- dents of Precambrian geology (for example, Anhaeusser and others, 1969) are reluctant or unable to interpret the older rocks of southern Africa in terms of plate-tectonic events. Anhaeusser and others (1969) and Coward and others (1976) have interpreted the Precambrian tectonics of southern Africa in terms of intracratonic block tectonics; this process consisted of relatively small movements of older microcontinents or cratons with respect to each other and a resulting high degree of deformation and metamorphism of the intervening younger sedimentary and volcanic rocks that had been deposited on a cratonic basement. Goodwin (1973) has stated quite correctly that evaluation of a platetectonic model for the Precambrian must rest principally on geological analogy to more recent models. He examined two supracrustal elements of Precambrian crust-the chemistry of the Archean volcanic belts (with ages of 2.7 and 3.1 billion years (b.y.) and the distribution of lower Proterozoic banded iron formations (ages between 1.9 and 2.1 b.y.) and concluded that compositions, origins, and distribution patterns are compatible with a global pattern of plate boundaries and some form of intraplate motion. Burke and Dewey (1973) have suggested that plate-tectonic patterns may be extrapolated back into the Proterozoic Eon and that modern continental-collision (Himalayan) orogenies may be models for later Precambrian tectonics. They regard plate tectonics as a secular process involving an increasing rigidity of lithospheric blocks. Before about 2.5 b.y. ago, a radically different tectonic regime (the Permabile Phase) prevailed. This phase was the expression of a thin lithosphere characterized by high heat generation and the absence of extensive areas of rigidity. 
The purpose of this paper is to reinterpret a large segment of the older Precambrian rocks of the Brazilian shield in rather simplified terms of plate tectonics. The elements of our interpretation involve the recognition of an ancient craton (age greater than 2.6 b.y.) and the obduction onto this craton of a structural block containing a thick accumulation of little-metamorphosed flyschoid sedimentary and volcanic rocks. Rather than containing only the reworked material of the older cratonic basement, this thrust block contains disrupted peridotite-gabbrovolcanic-chert units, suggesting an ophiolitic association, and thick marine sediments, which include widely scattered iron-formations of carbonate facies. By analogy with modern examples of plate tectonics, these rocks would seem to represent a continentaloceanic-plate convergent margin as opposed to the continental-plate intersections proposed for the areas of the Precambrian, which were discussed by Burke and Dewey (1973).

Our area of investigation is the Quadrilatero Ferrifero, one of the great mining areas in the world, a region of about $7,000 \mathrm{~km}^{2}$ in central Minas Gerais, Brazil. Between 1946 and 1962, a joint team of geologists from the Departmento Nacional da Produçáo Mineral of Brazil (D.N.P.M.) and the U.S. Geological Survey (U.S.G.S.) carried out a program of geologic mapping of the Quadrilatero under the auspices of the Agency for International Development (A.I.D.) of the U.S. Department of State. The objectives of this work were to evaluate the economic potential of the vast iron-formations of the region and to set up a stratigraphic and structural framework for the iron-formations and surrounding rocks. In this, the team was very successful; their work resulted in about 40 detailed geologic maps at $1: 25,000$, many topical papers, and a final synthesis by Dorr (1969), the program director. As a result, this is one of the geologically best known regions of Precambrian rocks in South America.

The Quadrilátero Ferrifero is about on the boundary between the old basement of the São Francisco platform (2.6 b.y.) and the remobilized zones to the east (Ferreira, 1972). The stratigraphy and general geology as summarized by Dorr (1969) are shown in figures 1 and 2 . In addition, Herz has reported at some length on the gneisses and granitoid rocks (1970), and on the metamorphism of the sedimentary rocks (1978).

The area is underlain by gneiss and foliated granitoid rocks and three major series of sedimentary and subordinate volcanic rocks set off from each other by angular unconformities. The oldest series,

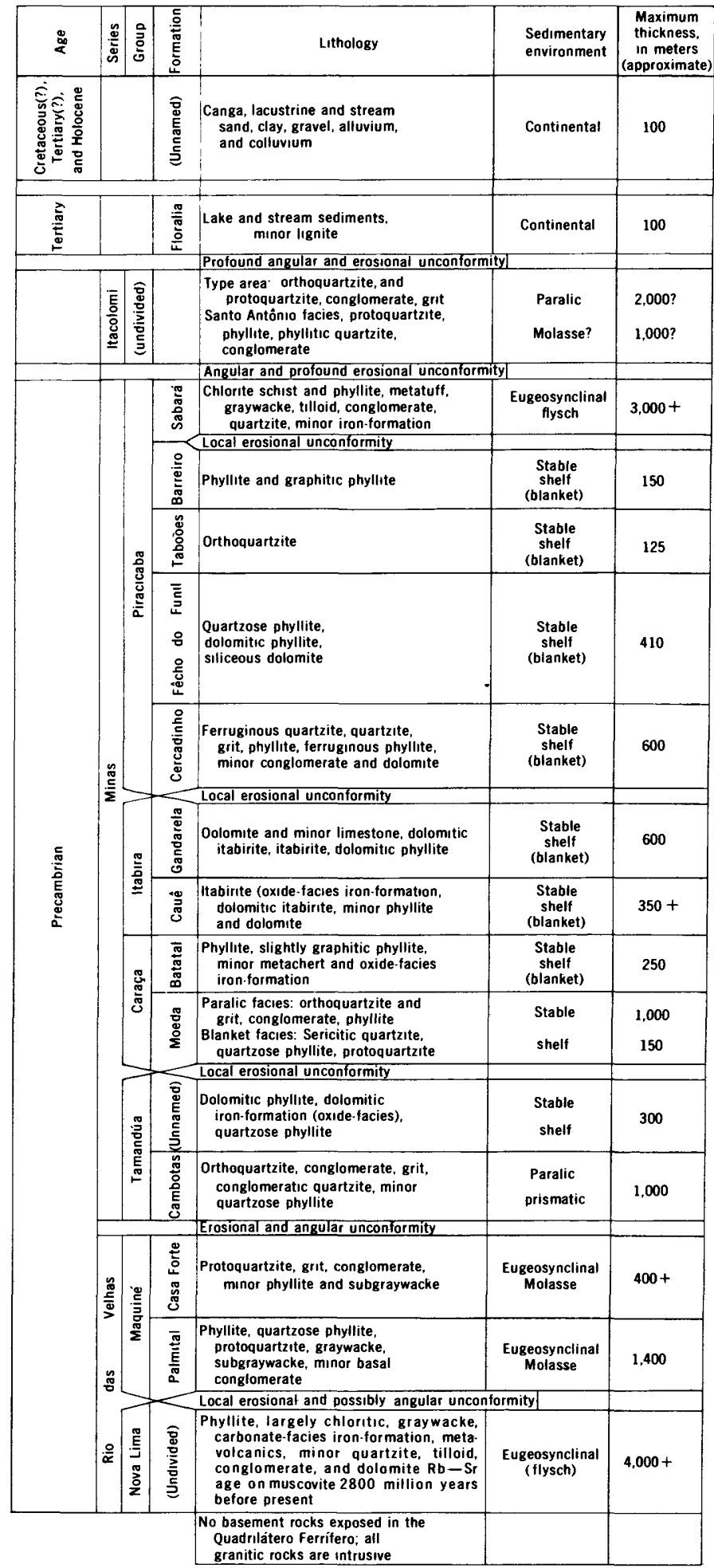

FIGURE 1.-Stratigraphic section in the Quadrilátero Ferrífero, Minas Gerais (modified from Dorr, 1969).

the Rio das Velhas, is a eugeosynclinal suite that is interpreted to pass up into a molasse, at least locally. These rocks are overlain by the Minas Series 
of largely shallow-water sediments, including the great deposits of iron-formations (oxide facies). The upperment rocks of this sequence are thought to be flysch. The youngest series, the Itacolomi, consists of rocks thought to represent molasse and paralic deposits. The sedimentary and lesser volcanic rocks of these three series have been regionally metamorphosed, primarily in greenschist facies, although staurolite-bearing schists of the amphibolite facies are present in some places.

Rocks of the Rio das Velhas Series are considered by Dorr (1969) to be the oldest in the Quadrilatero. All the gneiss and foliated granitoid rocks were interpreted to be intrusive into the sedimentary-volcanic pile and to be post-Rio das Velhas in age. The rocks in the amphibolite facies were thought to result from contact metamorphism and to be in thermal aureoles around granitoid intrusions. The Quadrilátero has, therefore, been interpreted as an island of metasedimentary rock floating in a sea of granite (Dorr, 1969).

The geologic map of the Quadrilátero (fig. 2) shows the area to be one of extraordinary structural complexity. The outcrop distribution is that of a Type I (eggbox) fold-interference pattern (Ramsey, 1967), very similar to those patterns formed in granitic gneiss-metasedimentary terranes in the Canadian shield (see particularly Pearson and Lewry, 1974, fig. 5).

Because of extensive geologic research in the area, the Quadrilátero was chosen to serve as a field area for training experienced geologists of the various agencies of the D.N.P.M. in advanced geologic field techniques. Such courses were held during the austral winters of 1974 and 1975. Through an A.I.D.-sponsored cooperative program between the U.S.G.S., D.N.P.M., Department Nacional de Aguas e Energia Eletrica (D.N.A.E.E.), and Companhia de Pesquisa de Recursos Minerais (C.P.R.M.), Drake served as an instructor for the 1974 and 1975 courses, and Morgan, for the 1975 course.

The tectonic model for the Quadrilátero Ferrífero presented here is contrary to some conclusions made by earlier workers. Our paper is organized into two major sections: (1) the granitoid craton, in which is presented our arguments for the presence of an ancient continental massif and (2) the Rio das Velhas Series, in which is presented our arguments for the presence of a major thrust sheet containing blocks of disrupted ophiolite.

\section{ACKNOWLDGMENTS}

This paper could never have been conceived without the excellent geologic maps of Dorr and his coworkers. As Dorr has written $(1969$, p. 5), "As the knowledge of the region grew and evolved, interpretations made early in the work, although seemingly well based at the time, became obsolescent, just as any interpretations made in this report will also become obsolescent after more detailed work is done in the future."

Our reinterpretation of the older rocks of the Quadrilátero is made in the same spirit. We hope that the possibility of a major plate-tectonic event in the Archean in this area will spur other geologists to work in the Quadrilatero Ferrifero and that the understanding of this fascinating area will continue to expand.

We are indebted to our teaching colleagues in the Brazilian field courses, J. M. Aaron and C. H. Thorman of the Geological Survey and V. J. Hurst of the University of Georgia, for many observations in the field. We are indebted to Samir Nahass and Pedro Gervasio Ferrari of the Companhia de Pesquisa de Recursos Minerais for help with logistical details. Finally, we express our thanks to the 48 students with whom we worked, both for their interest in our studies and their problem-solving strip mapping.

\section{THE GRANITOID CRATON}

A wide variety of granitoid rocks and gneiss, including paragneiss and foliated granidiorite, is shown as an undivided unit in figure 2. These rocks almost completely surround the Quadrilátero Ferrifero and also form a prominent massif, the Bação Complex, within the district. The extreme weathering of these rocks has prevented detailed mapping by the D.N.P.M.-U.S.G.S. workers; structures and lithologies were impossible to extrapolate over large areas devoid of all data. With the exception of Simmons' (1968a) mapping in the western part of the area, all the detailed quadrangle maps at a scale of 1:25,000 show granitoid rocks and feldspathic gneiss as an undivided unit; however, many of these workers have given different names to granitoid massifs separated by metasedimentary septa, and many also have mapped out minor bodies of chert and amphibolite within the granitoid terrane where it proved practicable. Simmons (1968, pls. 1 and 2), working in the Bonfim dome, and Wallace (1965, fig. 8), in the Bação Complex were able to map large areas underlain by foliated rocks of probable igneous 


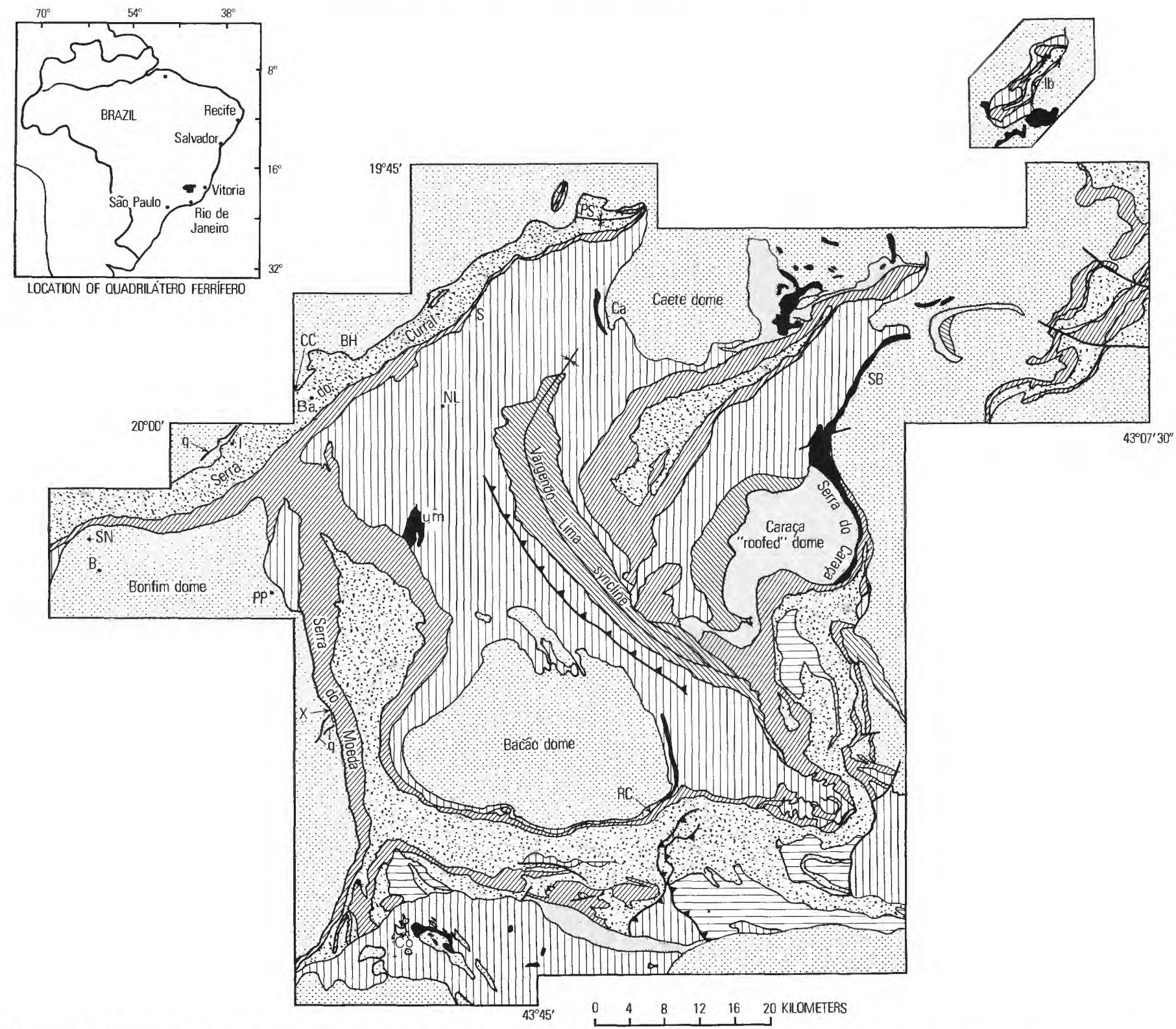

Figure 2.-Generalized geologic map of the Quadrilátero Ferrifero, Brazil. Some places on map that are mentioned in the text: SN, Souza Nocheso; B, Brumadinho; q, areas of cataclasite mapped as quartzite; I, Ibirité; PP, Piedade do Parapeba; X, contact of Moeda with sheared granite; CC, contact of cataclastic granodiorite with phyllonized staurolite schist; Ba, Barreiro; um, ultramaflc and mafle rocks in Rio Acima and Macacos quadrangles; Co, Congonhas; BH, Belo Horizonte; NL, Nova Lima; S, Sabará; Ca, Caete; RC, railroad cut exposing contact of staurolite schist and Moeda Quartzite; SB, Santa Barbara; Ib, Itabira; PS, Piedade syncline; Igarape is off map about $15 \mathrm{~km}$ northwest of Souza Nocheso.

origin as well as areas underlain by gneissic rocks of probable sedimentary origin. Herz (1970), in a survey of the granitoid rocks of the Quadilatero, extended the mapped contacts of Simmons and Wallace in the Bonfim and Bação Complexes and showed that these massifs consist of a core of metaigneous rocks surrounded by a mantle of gneiss, which he thought was derived from ultrametamorphism of sedimentary rocks. In three other areas of the Quadrilátero, Herz (1970) was able to show contacts over limited distances between other foliated granitoids and metasedimentary gneiss.

Radiometric age determinations on granitoid rocks and gneiss from the Quadrilátero were published by Herz and others (1961), Aldrich and others (1964), Pinson and others (1967), and Herz (1970) and have been summarized by Herz (1970). These data for the Quadrilátero yield a wide scatter 
EX P L A N A T I O N

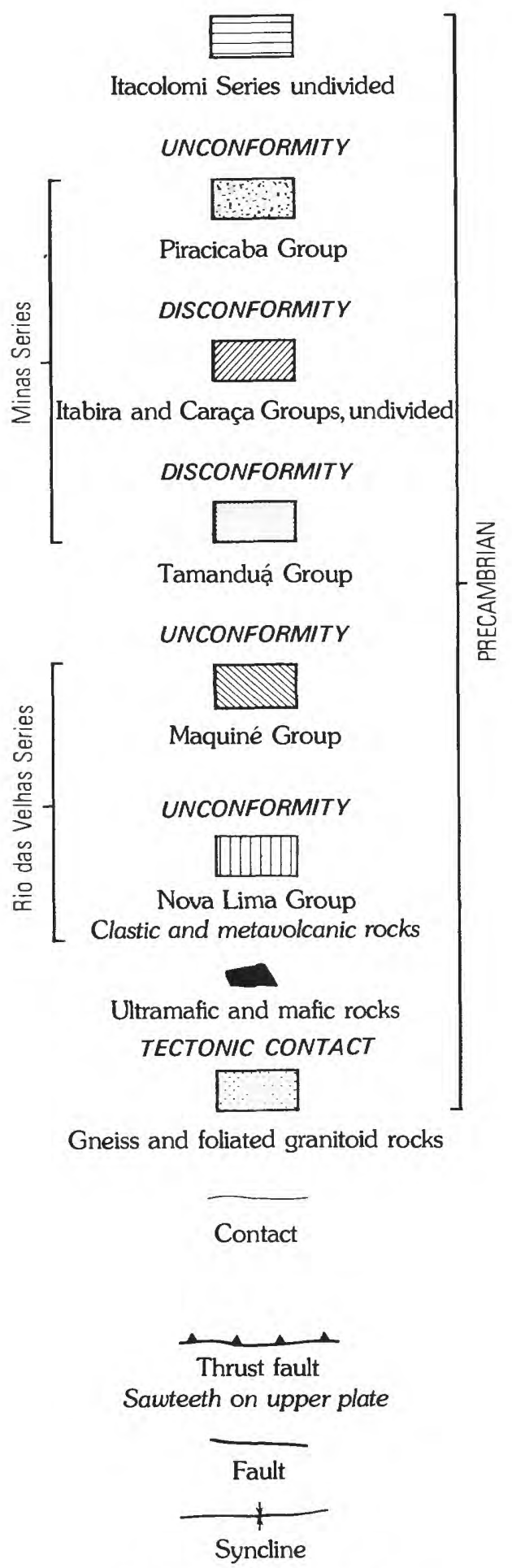

FIgure 2.-Continued.

of ages ranging from 2,790 to 420 m.y. In general, $\mathrm{K} / \mathrm{Ar}$ ages are younger than the corresponding $\mathrm{Rb} / \mathrm{Sr}$ ages from the same sample, frequently by more than a billion years. Age determinations on biotites show a particularly large range and a large number of dates between 975 and $420 \mathrm{~m}$.y. that probably are the result of Ar loss. Table 1 gives a summary of age data from the Bação and Bonfim Complexes. All of the multiply determined ages from the same samples are discordant for these complexes. $\mathrm{K} / \mathrm{Ar}$ ages on biotite from foliated granodiorite in the core of the Bação Complex (2,440 and 2,510 m.y.), Rb/Sr ages on feldspar from gneiss from the Bonfim Complex (2,300 m.y.), Rb/Sr ages from muscovite from amphibolite in the Bação paragneiss $(2,675 \mathrm{m.y.})$, and $\mathrm{Rb} / \mathrm{Sr}$ ages on muscovite from the metasedimentary rocks immediately north of the Bação Complex (2,790 m.y.) give a more restricted range of older ages for the district, despite the wide diversity of rock types. Contrary to the conclusion of Herz $(1970$, p. B9), we conclude that as these ages were determined from minerals derived by metamorphic processes, the ages must be partly or completely reset by metamorphism and do not reflect the time of implacement of plutonic sequences such as the granodiorite in the core of the Bação Complex. Until detailed work has been carried out using $\mathrm{U} / \mathrm{Pb}$ methods on zircons from these granitoid rocks, we feel that the ages of these rocks are uncertain; however, the rocks most probably are older than 2.5 b.y. and were affected by metamorphism at about that time, as well as by later thermal events (in agreement with Herz, 1970) at about 1,350, 1,000 , and 500 m.y.

Prior to the work of the D.N.P.M.-U.S.G.S. team, most workers interpreted the gneiss and foliated granitoid rocks of the area to be basement to the Nova Lima Group in the Rio das Velhas Series, although some workers in the 1950's interpreted some of the gneiss to be the result of granitization. Dorr (1969) and Herz (1970) differed with the earlier interpretations and considered all granitoid rocks to be intrusive into the metasedimentary rocks of the area. Herz divided these rocks into an earlier pre-Minas suite of granodiorite and quartzo-feldspathic gneiss and a later post-Minas suite of granite and gneiss. He concluded that the gneiss may have originated by ultrametamorphism of sedimentary rocks and also that some of the granodiorite and granite may have crystallized from anatectic melts. The granodiorite and granite were considered to be younger than the Rio das Velhas Series, and much of the gneiss was thought to be granitized Nova Lima schist. The interpretation of Dorr and Herz on the intrusive nature of the granitoid rocks has been disputed in several more recent publications. For example, de Almeida and others (1973), in a 
TABLE 1.-Summary of isotopic age dates for the Bação and Bonfim Complexes, Quadrilátero Ferrífero, Minas Gerais

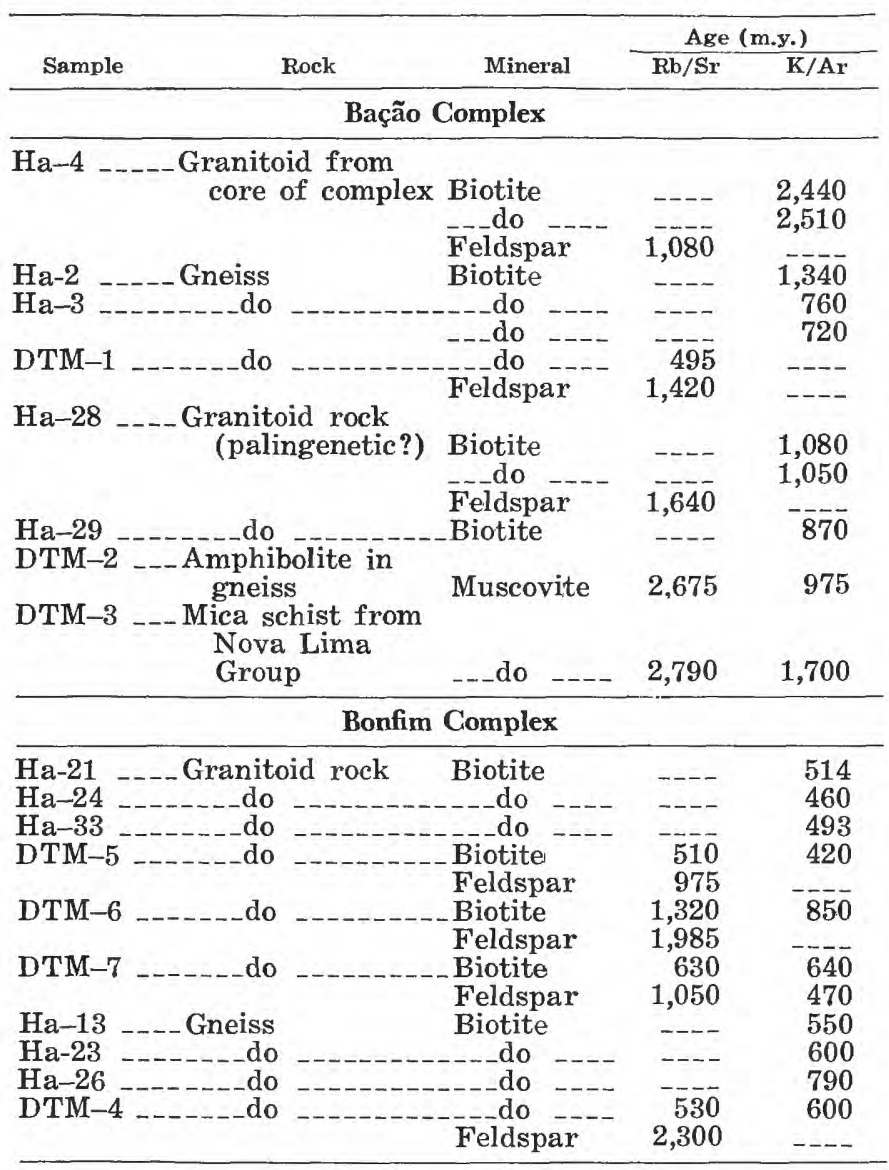

summary of the Precambrian geology of Brazil, continued to regard these rocks as a basement for the overlying metasedimentary strata. Similarly, Fleischer and Routhier (1973), in a study of gold deposits in the southeastern part of the Quadrilátero Ferriferro, considered the gneiss and granitoid rocks as basement to the metasedimentary sequence.

Our interpretation of the gneiss and granitoid rocks in the Quadrilátero differs markedly from that of Dorr (1969) and Herz (1970). On the basis of investigations of these rocks in the Belo Horizonte area as well as in the Bonfim and Bação Complexes, we have concluded that the gneiss and granitoid rocks represent a part of the ancient São Francisco craton and have an age in excess of 2.5 b.y. The Rio das Velhas Series, a graywacke-shale (flysch) sequence containing exotic blocks of disrupted ophiolite, was thrust over that craton and metamorphosed for about 2.5 m.y. After a period of erosion, the Minas and Itacolomi Series were deposited on the eroded remnants of the Rio das Velhas rocks and the exposed craton. At an unknown time (but perhaps at about 1,350 m.y.), a major orogenic event was characterized by the diapiric protrusion of the granitoid and gneissic cratonic rocks upward into the overlying sedimentary rocks, resulting in the formation of a series of mantled gneiss domes. Minor palingenetic magmas probably were generated at this time and intruded the mantling rocks in the form of small sills and apophyses; high heat flow associated with the doming also may have resulted in some contact-metamorphic effects. The evidence for this interpretation of the history of the granitoid rock and gneiss in this area is given in the following paragraphs.

Large-scale, crosscutting intrusive relationships are not characteristic of the contacts between granitoid rocks and the metasedimentary rocks of the Quadrilátero. A careful examination of the 1:25,000scale maps made by the D.N.P.M.-U.S.G.S. team shows that the metasedimentary rocks are often exposed in thin sinuous ribbons around the boundaries of the gneiss and granitoid rocks. For example, the rocks of the Minas Series may be traced continuously around the Bonfim dome along the Serra do Moeda and westward to Brumadinho. (See fig. 2.) Nowhere along this trace of nearly $100 \mathrm{~km}$ are any typical intrusive contacts shown on the detailed maps (Simmons, 1968a; Pomerene, 1964; Wallace, 1965; Guild, 1957). A similar relationship is also apparent in the Rio Piracicaba area in the eastern part of the Quadilátero (Reeves, 1966). In the area of the Bação dome, the Minas Series rocks form thin continuous ribbons around the south and western flanks of the dome; however, palingenetic magmas have intruded Minas rocks at one locality on the south flank of the dome, and a larger apophysis of magma invaded the Nova Lima rocks on the north side of the dome (Dorr, 1969, pl. 6).

Relationships of granitoid rocks and gneiss with metasedimentary rock appear to be faulted rather than intrusive or unconformable, as evidence of extensive shearing and cataclastic textures is found along contacts. The contact zones between Nova Lima rocks (including an unnamed staurolite schist unit) and granitoid terrane are zones of profound shearing where rocks have been almost completely pulverized into mylonite.

Mylonitized granitoid rocks and gneiss have a cataclastic fabric along the northwest front of the Quadrilátero from Igarapé to Ibirité and Belo Horizonte, and eastward to the Piedade syncline (fig. 2). The granitic rocks within the Bonfim dome near Brumadinho and south along the west side of the Serra do Moeda have a similar fabric as do those in contact with metasedimentary rock near Caeté 


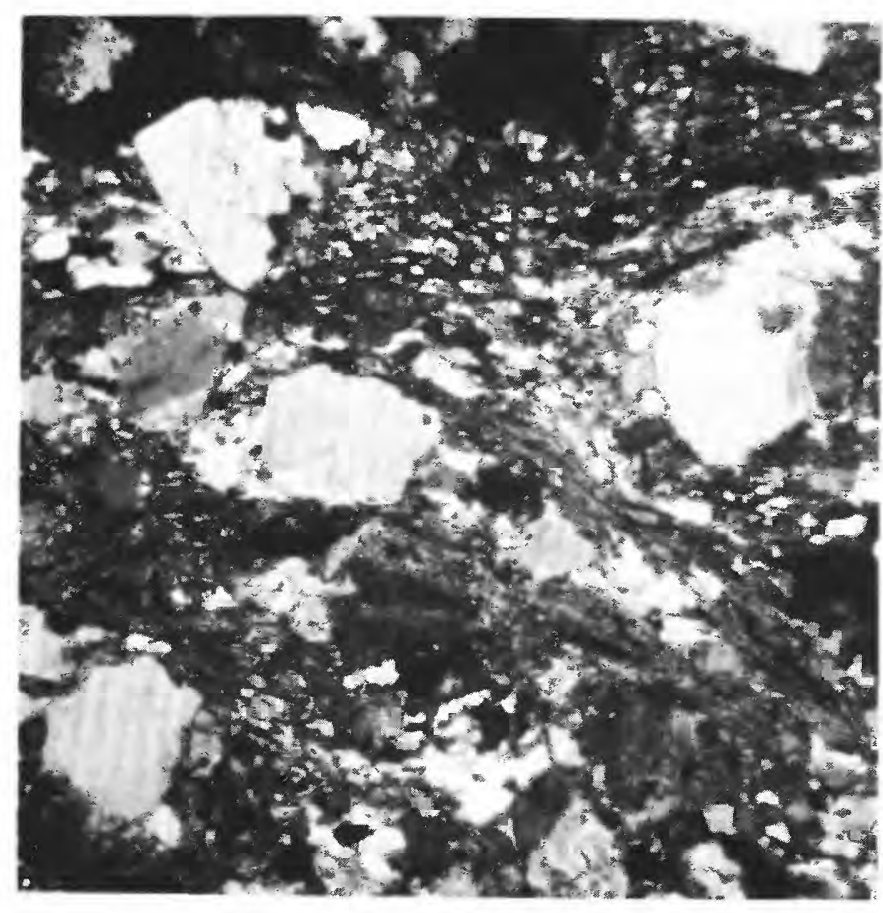

A

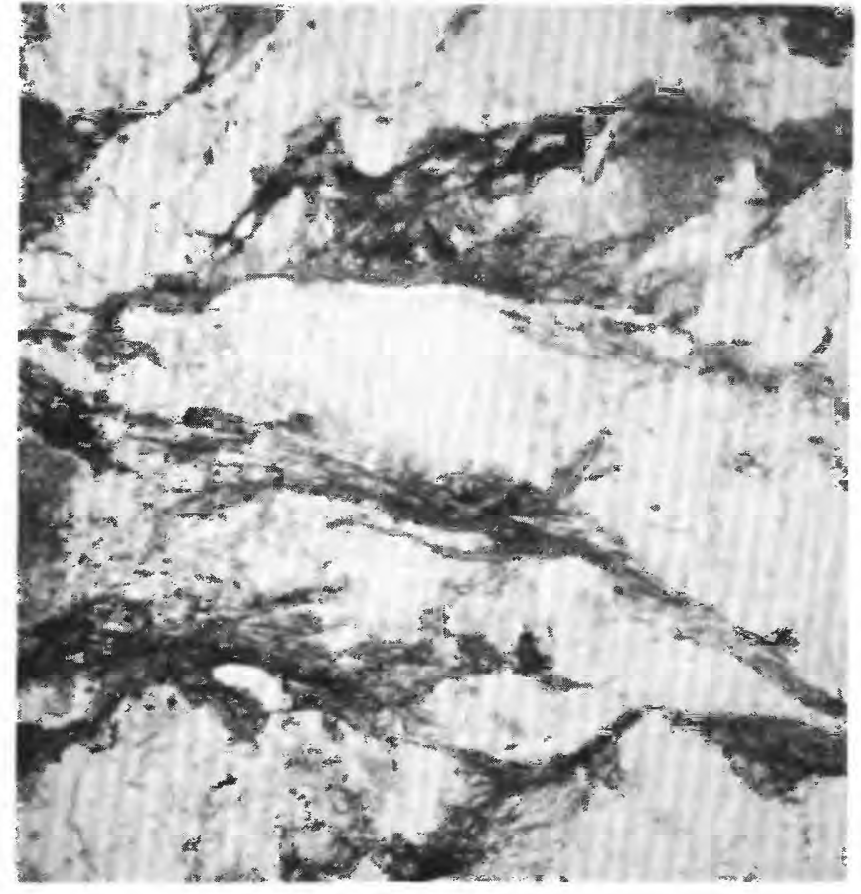

C

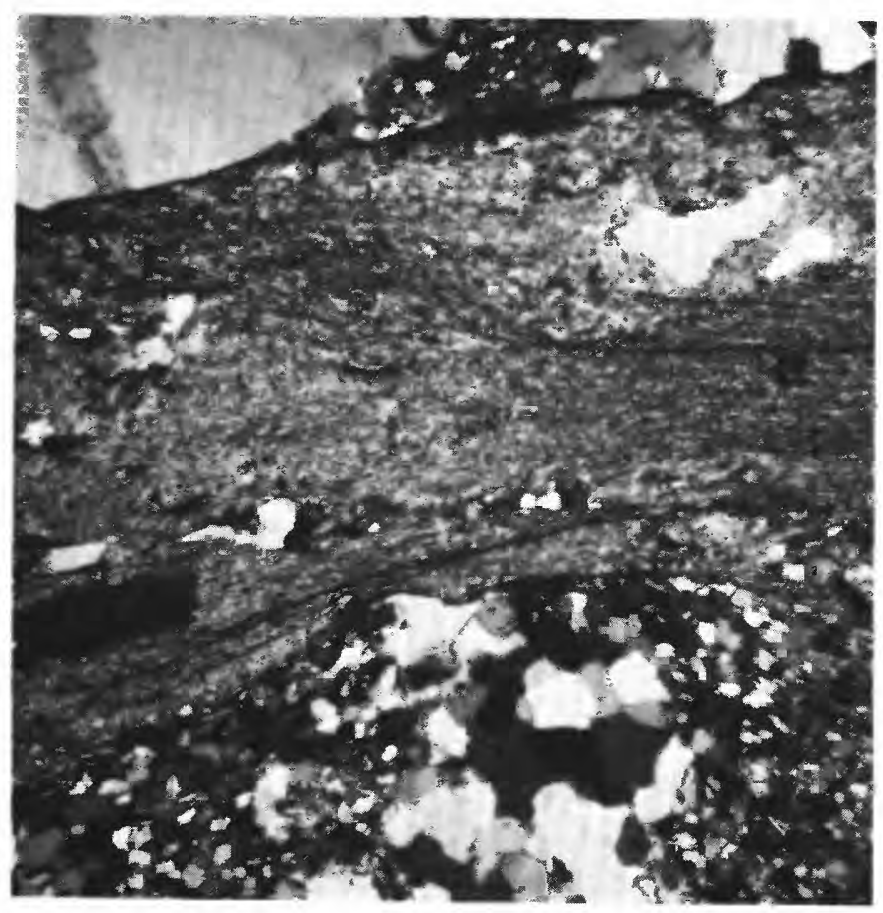

B

FigURE 3.-Photomicrographs of cataclastic granitoid rocks from the Quadrilátero Ferrifero, Plane polarized light. Width of view is $12 \mathrm{~mm}$. $A$, Granite beneath the Piracicaba Group near Igarapé. $B$, Granite beneath Moeda Quartzite, Serra do Moeda ( $\mathrm{X}$ on fig. 2). C, Granodiorite beneath chlorite phyllonite after staurolite schist on highway from Barreiro to the Industrial City of Brazil (CC on fig. 2). 
and within the Bação Complex. Typical cataclastic fabrics are shown in figure 3. Other evidence of shearing within the granitoid terrane consists of zones of "quartzite" near contacts with pre-Minas rocks (q on fig. 2). This "quartzite" was interpreted by Pomerene (1964) to be recrystallized chert of the Sabará Formation and to have survived granitization because of its bulk composition. A careful study of this material shows that it is ultramylonite derived by crushing and chemical alteration of the granitoid rocks and that its outcrop pattern parallels the cataclastic fabric in the granitoid terrane. Similar "quartzite" was described by Simmons (1968a) and may have had a similar origin, although we did not investigate these rocks in the field.

The pre-Minas rocks are also sheared where they are in contact with the granitoid rocks, the shear fabric being parallel to the contact. This relation is particularly well exposed along the highway between Barreiro de Cima and the Industrial City of Brazil, where a wide zone of chlorite phyllonite after staurolite schist is in contact with granodiorite; the phyllonite is retrograded to the greenschist metamorphic facies and has two cataclastic foliations (CC in fig. 2). The rocks at this locality are so severely deformed that it is virtually impossible to locate the contact between the schist and granitoid rock. Another excellent exposure showing highly sheared pre-Minas rocks is found on the road to Piedade do Paraopeda on the west flank of the Serra do Moeda (just east of PP in fig. 2). At this place, severely sheared ultramafic rock and Nova Lima phyllonite are in contact with ultramylonite, mylonite, and granitic augen gneiss. At this locality, the cataclastic fabric also parallels the contact.

A comparison of tectonite fabrics of the g:anitoid rocks and gneiss and the sedimentary rocks shows that the granitoid rocks and gneiss have a complex tectonite fabric coupled with metamorphic differentiation into a layered sequence. The gneisses are in the amphibolite facies of the regional metamorphism and were derived from sedimentary or volcanic rock or from metamorphically differentiated intrusive rock. The gneisses have undergone severe strain as shown by floating folds and multiply folded folds; thus, these rocks are complexly polydeformed. An example of fold interference that is very common in these rocks is shown in figure 4. We found no examples of a fabric of this kind within the metasedimentary-metavolcanic terrane of the Quadrilátero. A staurolite schist unit (see below) is polydeformed, but it shows no evidence of metamorphic differentiation or beginning anatexis. Rocks of the
Nova Lima Group have a good penetrative cleavage (schistosity) and in most places a strain-slip fabric; however, the Nova Lima rocks never have the extent or style of deformation of the granitoid terrane. Younger rocks in the Quadrilátero are often greatly deformed and are involved in overturned to recumbent folds, but, except for the staurolite schist, we have not observed more than one fabric element in these rocks; in many exposures, even a penetrative axial surface cleavage is lacking. An excellent example of this is in the overturned fold along the Serra do Curral south of Belo Horizonte, where a distinct tectonic break is evident between the rocks of the granitoid and gneiss terrane and those rocks above it.

Comparison of major rock types and chemical compositions of granitoid rocks and gneiss and those of the sedimentary rocks shows a great dissimilarity between the two groups of rocks. In table 2, average analyses of granitoid rocks and gneiss taken from Herz (1970) are compared with averages for graywackes, carbonate-rich phyllites, and pelites taken from Herz (1978). Although there is some chemical similarity between the analyses of the gneiss and the graywacke, the amount of graywacke in the Nova Lima Group is very minor. Most of the Nova Lima Group in the Rio das Velhas Series is composed of rocks that have lower $\mathrm{SiO}_{2}$ content and either higher $\mathrm{Al}_{2} \mathrm{O}_{3}$ (pelitic rock) or $\mathrm{CaO}$ content (calcareous phyllite) than does the quartz-feldspar-rich gneiss. Conversion of the pelites and calcareous phyllites to a quartz-feldspar gneiss would involve very extensive metasomatism, including migration of aluminum, an element usually considered to be relatively immobile

TABLE 2.-Comparison of the chemistry of gneiss with graywacke, pelite, and calcareous phyllite of the Nova Lima Group

\begin{tabular}{|c|c|c|c|c|}
\hline & Gneiss 1 & $\begin{array}{l}\text { Nova Lima } \\
\text { graywacke }\end{array}$ & $\begin{array}{c}\text { Nova Lima } \\
\text { pelite }^{3}\end{array}$ & $\begin{array}{l}\text { Nova Lima } \\
\text { calcareous } \\
\text { phyllite }\end{array}$ \\
\hline $\mathrm{S}_{\mathrm{i}} \mathrm{O}_{2} \ldots \ldots$ & 74.4 & 66.6 & 58.4 & 54.4 \\
\hline $\mathrm{Al}_{2} \mathrm{O}_{3}$ & 13.2 & 16.2 & 18.8 & 13.2 \\
\hline $\mathrm{Fe}_{2} \mathrm{O}_{3}$ & .65 & 1.1 & 3.8 & 1.8 \\
\hline $\mathrm{FeO}$ & 1.2 & 2.8 & 5.7 & 5.8 \\
\hline $\mathrm{MgO}$ & .40 & 1.6 & 3.7 & 7.3 \\
\hline $\mathrm{CaO}$ & .80 & 3.3 & .36 & 3.9 \\
\hline $\mathrm{Na}_{2} \mathrm{O}$ & 2.4 & 4.4 & .60 & 2.0 \\
\hline $\mathbf{K}_{2} \mathbf{O} \ldots$ & 5.0 & 1.8 & 3.6 & 1.8 \\
\hline $\mathrm{H}_{2} \mathrm{O}$ & $\therefore 0$ & .54 & 4.1 & 4.0 \\
\hline $\mathrm{T}_{1} \mathrm{O}_{2}$ & .20 & .19 & .53 & .45 \\
\hline $\mathrm{P}_{2} \mathrm{O}_{5}$ & .05 & .06 & .10 & .07 \\
\hline $\mathrm{MnO}$ & .04 & 1.5 & .09 & .05 \\
\hline $\mathrm{CO}_{2} \ldots$ & .27 & .22 & $<.05$ & 6.2 \\
\hline Total - & 99 & 100 & 100 & 100 \\
\hline
\end{tabular}

- Analyses from samples Ha-21, Ha-23, J-82, $\mathrm{Ha}-11, \mathrm{Ha}-19, \mathrm{Ha}-7$, $\mathrm{Ha}-36$, Ha-38 (Herz, 1970)

2 Analysis from sample JG-241-55 (Herz, 1978).

3 Analyses from samples 2-842, A-4953 (Herz, 1978).
${ }^{4}$ Analyses from samples C-5, C-8, 2148, 2554 (Herz, 1978). 


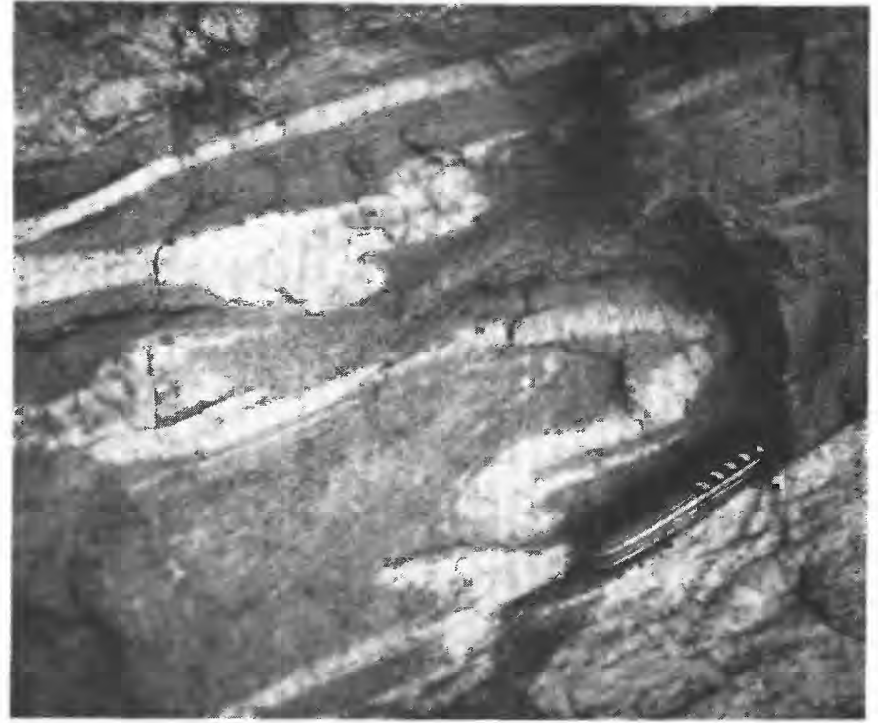

A

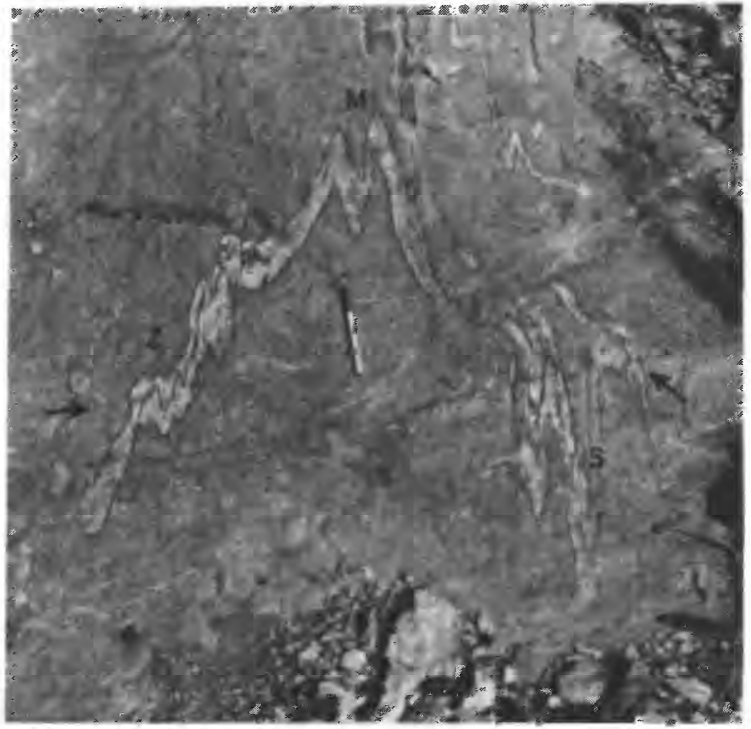

C

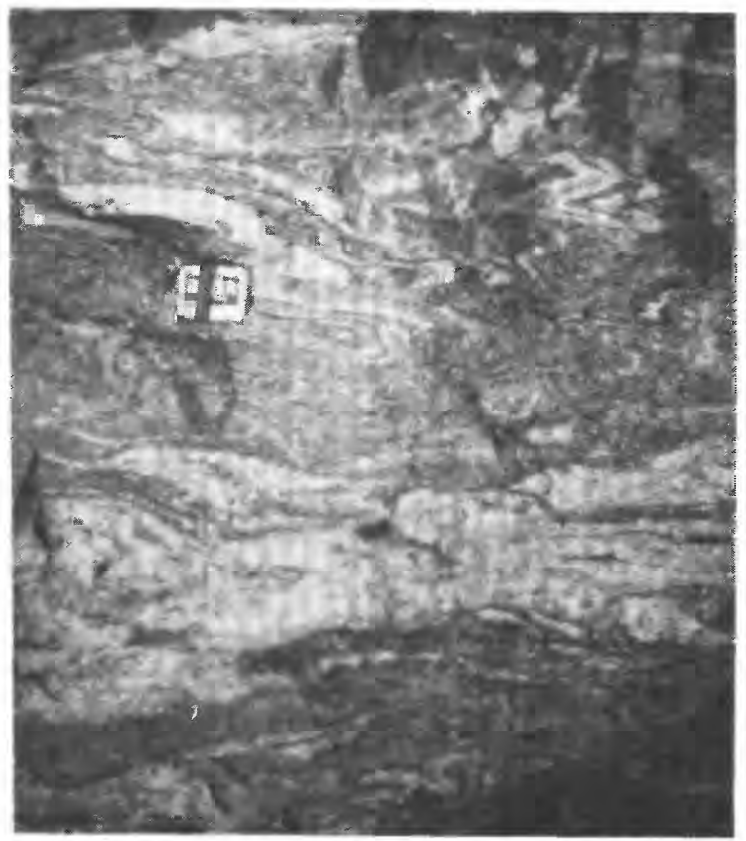

$B$

FIGURE 4.-Polyphase folds in the granitoid terrane along the north front of the Quadrilátero Ferrifero. $A$ and $B$, Two sets of recumbent folds in gneiss beneath staurolite schist along Rio das Velhas north of Sabará. $C$, Type III foldinterference patterns (between arrows) in gneiss beneath staurolite schist near Igarape. Z, M, and S refere to rotation sense of second-generation folds.

during metasomatic exchange. The greenschist metamorphic facies of the Nova Lima Group and the amphibolite facies of the gneiss (now retrograded to greenschist facies) do not suggesit that tempera- tures were attained during regional metamorphism that would result in the ultrametamorphism of the Nova Lima rocks and conversion of a large part of it to a monotonous sequence of quartz-feldspar 


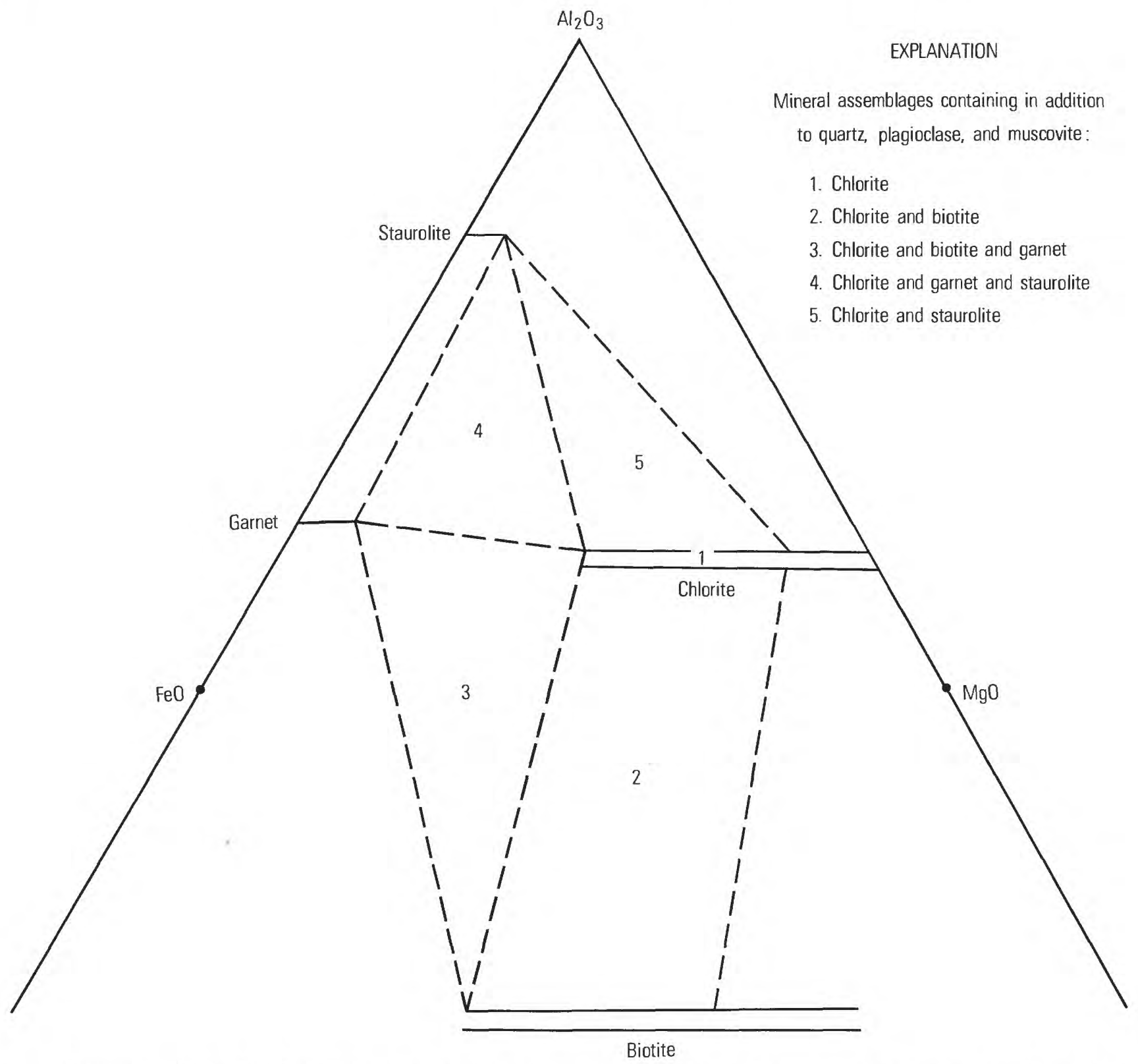

FIgURe 5.- $\mathrm{Al}_{2} \mathrm{O}_{3}-\mathrm{Mgo}-\mathrm{FeO}-\mathrm{K}_{2} \mathrm{O}$ projection with tielines for mineral assemblages reported for the staurolite schist.

gneiss in the areas of the Bonfim and Bação domes, as suggested by Simmons (1968a) and Herz (1970).

The presence of staurolite schist along many contacts with granitoid rocks has been interpreted as a contact-metamorphic aureole produced by the intrusion of the granitoid rock (Dorr, 1969). A compilation of metamorphic facies and zones by Herz $(1978$, pl. 1) has shown that staurolite schist in contact with granitoid rock extends all along the Serra do Curral, partly around the granitoid core of the Bação dome, and over a large area in the extreme southern part of the Quadrilátero; however, the staurolite rocks are absent in the northwest part of the Quadrilátero. We have reexamined the staurolite schists in the Rio das Velhas section first described by Gair (1962) and along the south flank of the Bação dome and have concluded that these higher grade schists are pre-Nova Lima in age and metamorphism and either rest unconformably on the granitoid terrane or form a thrust sheet emplaced over the granitoid rocks and gneiss before the thrusting of Nova Lima rocks.

The staurolite schists described by Gair (1962) are in the Rio das Velhas area north of Sabará (just north of S in fig. 2) ; Gair placed these rocks in the Sabará Formation within the Minas Series. This 


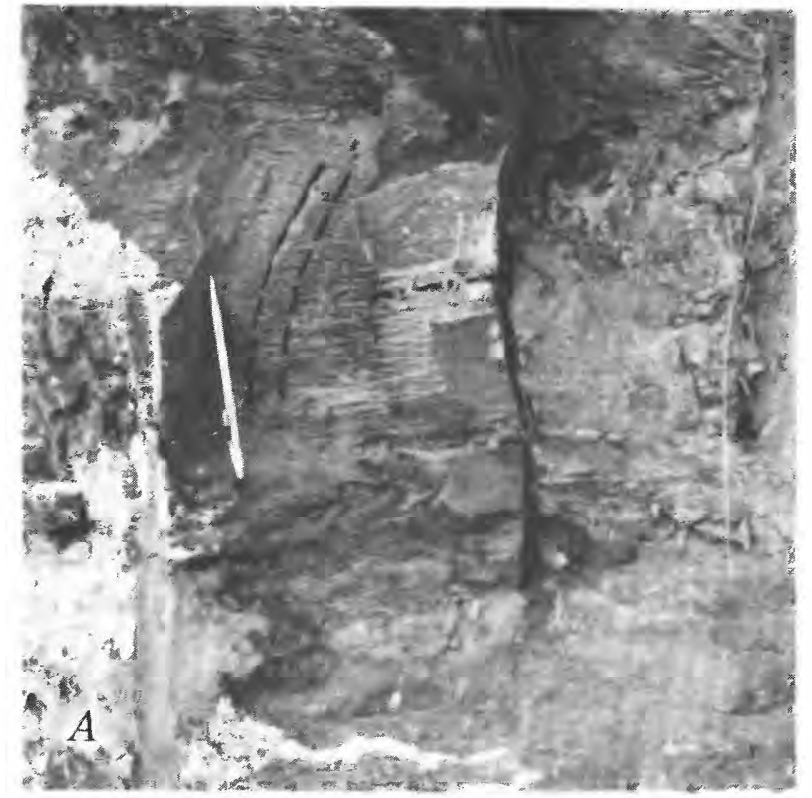

FiguRe 6.-Schists from the Quadrilatero Ferrifero. $A$, Staurolite-garnet schist from valley of the Rio das Velhas north of Sabará. Flat foliation is secondgeneration schistosity that is axial surface cleavage to folds in first schistosity. Hinges can be seen to right of pen. $B$, Proximal graywacke of Sabará Formation from new railroad cuts south of Ibirité. Beds top to the left (north) as shown by grading (dark part of beds are coarse, light parts are fine).

formation was mapped in two parts, one part altered by contact metamorphism and another part affected only by low-grade regional metamorphism. We have found that the low-grade part of the sequence is both pelitic and semipelitic and contains abundant interbedded graywacke and intervals 50 to $100 \mathrm{~m}$ thick of very proximal graywacke. Graded beds, Cinterval cross lamination, and abundant sole marks are beautifully developed. These Sabará rocks are in the regional greensichist facies and have only one penetrative cleavage, a cleavage often absent in the thicker graywackes. Bedding in these rocks can be seen in most exposures. The staurolite-bearing part of the sequence is almost entirely pelitic. The basic mineral assemblage is quartz-muscovite-plagioclase and biotite-chlorite-garnet or chlorite-garnet-staurolite. The most common assemblage, however, is quartz-muscovite-plagioclase-chlorite. The presence of coarse-grained conspicuous biotite, garnet, and staurolite is dependent on more extreme compositional variations in the rock sequence. Quite coarse-grained staurolite was found by Gair (1962) and by us near the granitoid terrane; staurolite was also found by us as fine-grained crystals in thin sections of rocks from areas of supposed lower grade,

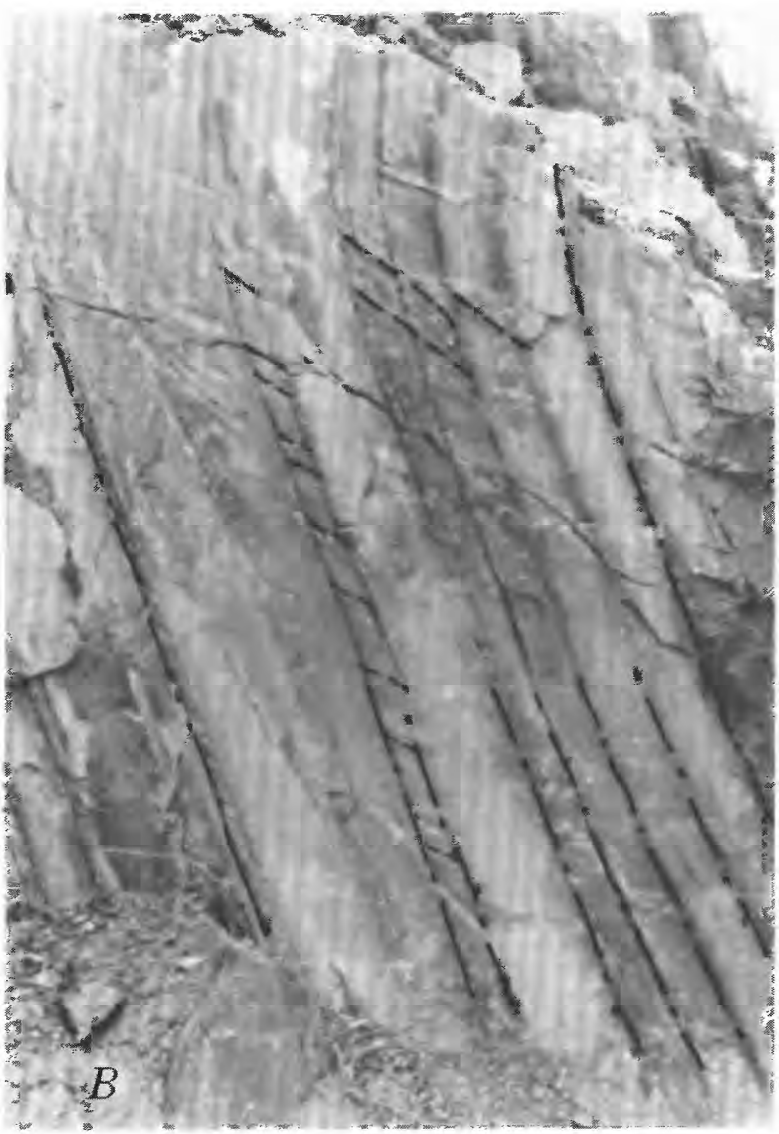

where rocks are dominantly quartz-muscovite-plagioclase-chlorite. The suggested prograde zonation crosses no tielines of a Thompson-type $\mathrm{Al}_{2} \mathrm{O}_{3}-\mathrm{MgO}$ FeO- $\mathrm{K}_{2} \mathrm{O}$ projection (fig. 5), and the appearance of coarse-grained staurolite is the function of sediment composition rather than a thermal gradient.

The staurolite-bearing part of the Sabará section is so severely deformed that sedimentary structures other than sparse disrupted beds cannot be seen. The staurolite-bearing rocks have been deformed at least three times (fig. 6). Staurolite and garnet porphyroblasts, both megascopic and microscopic, grow in the second schistosity (the flat foliation in fig. 6), which is axial surface to folds in the first schistosity. This texture is not typical of those formed by contact metamorphism.

The contact between these two rocks units is abrupt, knife-edged, and well exposed in new highway cuts. We conclude, therefore, that the staurolite-bearing rocks are a different sedimentary sequence that has a faulted contact with the low-grade rocks and that cannot be a part of a thermal aureole.

The staurolite schist mapped as Sabará Formation can be traced along the Serra do Curral both east and west of the valley of the Rio das Velhas. 
It is especially well exposed along the highway between Barreiro de Cima and the Industrial City of Brazil (east of $\mathrm{CC}$ in fig. 2), and in the Ibirite area. The rock at these places is exactly the same as that north of Sabará in both lithology and structural fabric; the staurolite forms porphyroblasts in the second schistosity.

Staurolite-garnet schist identical in lithology and tectonic style was mapped as Nova Lima Group in exposures on the southeast border of the Bação Complex ( $\mathrm{RC}$ on fig. 2). In this area, the staurolite schist unit tectonically overlies sheared felsic gneiss and is unconformably overlain by Moeda Quartzite (fig. 7). The tectonic fabric in the staurolite schist is truncated by the unconformity and is folded with the bedding of the Moeda. There is no petrographic evidence of retrogressive metamorphism. Strain-slip cleavage is axial surface to these folds in the staurolite schist and parallels the cleavage in the Moeda. The staurolite schist in this area is severely deformed, and the lower part is a tectonic melange containing blocks of gneiss and pegmatite as well as disrupted blocks of the staurolite unit.

Along the east contact of the Bação Complex, the staurolite schist is cut out by a thrust fault that brings greenschist facies Nova Lima rocks in contact with granitoid rocks. Farther north along this contact, the staurolite schist emerges from beneath the Nova Lima thrust sheet and can be traced for

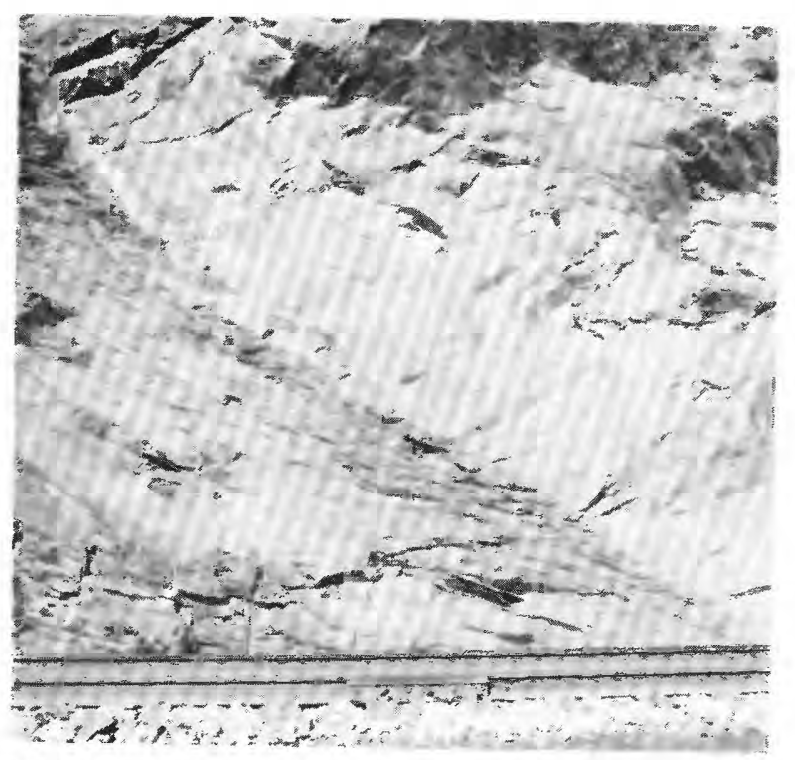

Figure 7.--Unconformable contact between staurolite garnet schist to left and Moeda Quartzite on southern flank of Bação dome. Both first and second schistosities in the staurolite unit are truncated by the unconformity. about another $7 \mathrm{~km}$, where it again is covered (Herz, 1978, pl. 1). The mapping by the D.N.P.M.-U.S.G.S. team clearly shows that both greenschist and amphibolite facies rocks are in contact with granitoid rocks of the Bação Complex, and we conclude that the staurolite schist does not result from contact metamorphism.

We propose that all the staurolite schist rocks are the same unit, whether mapped as Nova Lima Group or Sabará Formation. The distribution of this unit suggests strongly that it lies in tectonic lenses directly above the granitoid craton. Along the Serra do Curral, it is beneath a major thrust that brings rocks of the Piracicaba Group in contact with older rocks all along this mountain front. Around the Bação and Bonfim domes, it lies beneath thrusted Nova Lima Group or unconformably beneath rocks of the Minas Series.

Stratigraphically, the staurolite schist could be considered as the basal part of the Nova Lima Group of the Rio das Velhas Series on the basis of the original definition of that series as comprising all pre-Minas rocks. However, we believe that these rocks should be considered as a different sequence because of their different metamorphic and tectonic aspect. Whether the staurolite schist is parautochthonous or whether it is a different thrust sheet beneath the Nova Lima allochthon cannot be conclusively proved. If this unit is parautochthonous, it probably unconformably overlies the granitoid rocks, a view held by Brazilian geologists currently working in the Quadrilátero (Pedro Gervasio Ferrari, oral commun., 1975). If this is true, the lenses of staurolite schist might be tectonic slices that have been overridden and partly dragged along by the advancing Nova Lima thrust sheet. If the staurolite schist is a separate allochthon, then it arrived before the Nova Lima sheet.

In summary, our interpretation of the granitoid rocks and gneiss in the Quadrilátero is based on (1) a scarcity of well-defined, crosscutting relationships between metasedimentary rocks and granitoid rocks, (2) evidence for faulting between metasedimentary rocks and granitoid rocks, (3) contrasting tectonite fabrics between metasedimentary rocks, granitoid rocks, and gneiss, (4) contrasting chemistry between gneiss and the Nova Lima Group, and (5) a reinterpretation of the staurolite schist unit, which would rule out evidence for widespread contact metamorphism in the area. However, many workers of the D.N.P.M.-U.S.G.S. team have given evidence for small-scale transgressive contacts between granitoid rocks and metasedimentary rocks (for 
example, Moore, 1969; Wallace, 1965; Maxwell, 1972) and evidence for thermal metamorphism by the presence of small migmatite zones and the formation of feldspar- and tourmaline-rich zones in metasedimentary rocks at their contacts with granitoid rocks and gneiss (for example, Moore, 1969; Simmons, 1968b).

We suggest that all these data can be made compatible by interpreting the later history of these rocks in terms of the mantled-gneiss-dome concept first advocated by Eskola (1949) and later modified by Thompson and others (1968) and by Fletcher (1972). We also hasten to point out that both Simmons (1968a) and Herz (1970) have used the term "gneiss dome" in describing the Bonfim dome. They interpreted the dome as having been formed by the intrusion of granodiorite accompanied by extensive migmatization and ultrametamorphism of Nova Lima rocks to produce a mantle of gneiss. We contend, however, that the domes were produced during a later orogeny in which masses of granite and gneiss rose as diapirs and plastically accommodated themselves to the domal form structures in the heavier overlying (mantling) rocks. The formation of the mantled gneiss domes probably was accompanied by local palingenetic generation of magma; a higher than normal heat flow may have resulted in some contact metamorphism; however, the process was dominantly a plastic rather than a magmatic deformation. This interpretation is essentially the same as that advocated for the origin of gneiss domes in New England by Thompson and others (1968).

Our evidence for the presence of late-formed gneiss domes in the Quadrilátero is based in part on a reinterpretation of the maps and reports made by the D.N.P.M.-U.S.G.S. workers and compiled by Dorr (1969) and shown as our figure 2 and also by a study of the minor fold structures associated with a beautifully exposed contact of the Bação Complex with metasedimentary rocks in a railroad cut south of Santo Antonio dos Tabuões (RC on fig. 2). In this exposure, staurolite schist is tectonically above sheared granitic gneiss and is unconformably overlain by Moeda Quartzite. Planar structures (schistosities in the schist, bedding, and cleavage in the Moeda) dip to the southeast off the gneiss dome. Small folds in schistosity in the staurolite schist and bedding in the Moeda cascade down the flank of the dome, forming "Christmas tree" folds. The "Christmas tree" folds occur in both the old polydeformed rock and the Moeda Quartzite; clearly, no décollement is present between the two rock units.
The folds here resulted from a rotational couple caused by the drag on cover by the rising core of the dome. Attenuation of the cover by basement rise is shown by the severe tectonic thinning of the Moeda Quartzite along the south flank of the Bação dome (fig. 2).

These structural relations indicate that the Moeda and the rest of the Minas Series were in place on the staurolite schist and granitic basement here before the doming event. The doming, therefore, could not have been the result of pre-Minas intrusion, as visualized by Herz (1970). Neither could the doming be the result of post-Minas intrusion, as intrusive contacts are lacking and Minas Series pelitic rocks are at chlorite grade. Therefore, the granitoid rocks of the Bação Complex must have been deformed into a domelike structure along with the overlying metasedimentary and metavolcanic rocks. The doming is post-Minas and probably post-Itacolomi. The doming may have been coincident with a higher heat flow, which may be reflected in the wide scatter of age determinations shown in table 1 and reported by Herz (1970).

Other gneiss domes are probably present within the Quadrilátero (fig. 2). The Bonfim terrane is probably a mantled dome and was so called by Simmons (1968a). Relations on the west flank of this structure are somewhat more complicated in places, as along the road to Moeda on the Serra do Moeda (X on fig. 2), where Moeda Quartzite has been thrust onto sheared basement during post-Minas deformation. The roughly circular outcrop area of granitoid rocks east of Caeté ( $\mathrm{Ca}$ on fig. 2) is perhaps another gneiss dome. The uplifted area west of the Serra do Caraça is also possibly a mantled dome. If this last structure is a dome, it is still "roofed," but it is flanked by rocks of the Minas Series in a domelike pattern and has a dimensional similarity to the Bação and Bonfim domes.

The structural pattern of the Quadrilatero has been interpreted as resulting from the folding and faulting of a thick sequence of metasedimentary and metavolcanic rocks in a regional terrane dominated by giant buttresses of pre-Minas granitoid rocks. Our interpretation, however, is that the structural pattern results from the emplacement of broad gneiss domes and the attendant pinching of cover into tight polyoriented synforms.

\section{THE RIO DAS VELHAS SERIES}

A sequence of rocks older than the Minas Series and lying below an angular unconformity was first described by Dorr and others (1957) as the Rio das 
Velhas Series. This series was correlated with an unnamed "greenschist" series described by Guild (1957) and believed by him to be contemporaneous and in fault contact with the Minas rocks in the Congonhas district in the southwest part of the Quadrilátero Ferrifero. Dorr and others (1957) considered that the base of the Rio das Velhas Series was not exposed and that all contacts with granitoid rocks and gneiss were intrusive. Descriptions of the Rio das Velhas Series are found in Guild (1957), Gair (1962), Johnson (1962), Dorr and Barbosa (1963), Wallace (1965), Reeves (1966), Simmons (1968a), Moore (1969), Dorr (1969), and Maxwell (1972). Exceptionally complete lithologic descriptions are in Gair (1962), and a summary of stratigraphic interpretations was made by Dorr (1969). Dorr divided the series into two major groups-the widespread Nova Lima Group and the more restricted Maquiné Group.

The Nova Lima Group consists dominantly of chlorite, sericite, quartz-sericite, and, to a lesser extent, graphite-sericite phyllite. Chlorite-carbonate greenschist, probably of volcanic origin, is also abundant. Gair (1962) has estimated that the minimum thickness is at least $4,000 \mathrm{~m}$ in the northcentral part of the area shown in figure 2 in the Rio Acima quadrangle. Graywacke is an additional but minor component of the group. Iron formation of the carbonate facies is also present as small discontinuous lenses throughout the group, having an average thickness of 5 to $10 \mathrm{~m}$. In some areas, the iron formation grades into bedded chert (Dorr 1969). Because of extensive weathering, which selectively destroys volcanic rocks and graywackes, no worker in the area has been able to estimate with any degree of confidence the ratio of volcanic, volcaniclastic, and graywacke rocks to the more dominant phyllite units. Extensive weathering, low economic interest, and lack of key beds have all contributed to a very poor understanding of the structure and thickness of the Nova Lima Group.

Ultramafic and related mafic rocks are widespread in the Nova Lima Group and are not present in any other group of rocks within the entire Quadrilátero Ferrifero (Dorr, 1969). Figure 2 shows the general distribution of the larger ultramafic bodies within the area. All the ultramafic rocks are completely serpentinized to antigorite, talc, magnetite, and minor carbonate and are present as small, highly sheared tectonic blocks that crop out over areas of as much as $8 \mathrm{~km}^{2}$. The ultramafic rocks are intimately associated with metagabbro (for example, in the Rio Acima quadrangle (Gair, 1962) and the Itabira district (Dorr and Barbosa, 1963)) and with greenstone (or greenschist) sequence of metavolcanic rocks (for example, the Congonhas area (Guild, 1957) and the Serra do Caraça (Maxwell, 1972)). Outcrops of ultramafic rocks are characteristically (although not invariably, see fig. 2) in a section of the Nova Lima Group just at or near the sheared contact with granitoid rocks. At places, however, there are intervening tectonic lenses of staurolite schist. The association of lenses or tectonic blocks of ultramafic rocks with fragments of metagabbro and extensive metavolcanic rocks, all in a part of a thick flysch sequence, suggests to us that fragments of a disrupted ophiolitic sequence are present in the Nova Lima Group. In the following paragraphs, the principal occurrences of the ultramafic and associated rocks in the Quadrilátero Ferrífero are described.

The Maquiné Group is exposed in a syncline east of the Rio das Velhas and is believed by Gair (1962) and by Dorr (1969) to overlie the Nova Lima Group with an angular unconformity; however, many of the contacts appear to be faulted (Moore, 1969). The group contains sericitic quartzite, quartzose phyllite, and conglomerate beds. Total thickness ranges from a composite total of about $2,000 \mathrm{~m}$ down to a featheredge along erosional contacts. Volcaniclastic rocks and greenschist are absent, as are ironformation and carbonate rocks.

Dorr (1969) has considered the Nova Lima Group to be typical of a graywacke shale (flysch) suite, as described by Pettijohn (1957), on the basis of its thickness, predominantly argillaceous nature, and general scarcity of carbonate rocks and quartzite. The Maquiné Group is considered to be a typical molasse suite on the basis of the presence of basal conglomerates and an increase upwards in the section of quartz and subgraywacke, finally progressing to clean quartzite and grits. The Rio das Velhas Series rocks "seem to form a single evolutionary stratigraphic entity reflecting a progression from eugeosynclinal to paralic sedimentation" (Dorr, 1969, p. 27).

Serpentinite and talc schist underlie an area of about $8 \mathrm{~km}^{2}$ in the Rio Acima and Macacos quadrangles (u on fig. 2) ; a smaller outcrop of metagabbro covers an area of about $4 \mathrm{~km}^{2}$. The field relations of these rocks are shown in figure 8. Serpentinite is massive, dark to pale green, and contains no relict minerals. The mineral assemblage is antigorite and minor talc, magnetite, and carbonate. Many rocks are nearly monomineralic antigorite. Weathering textures suggest that the rocks originally were 


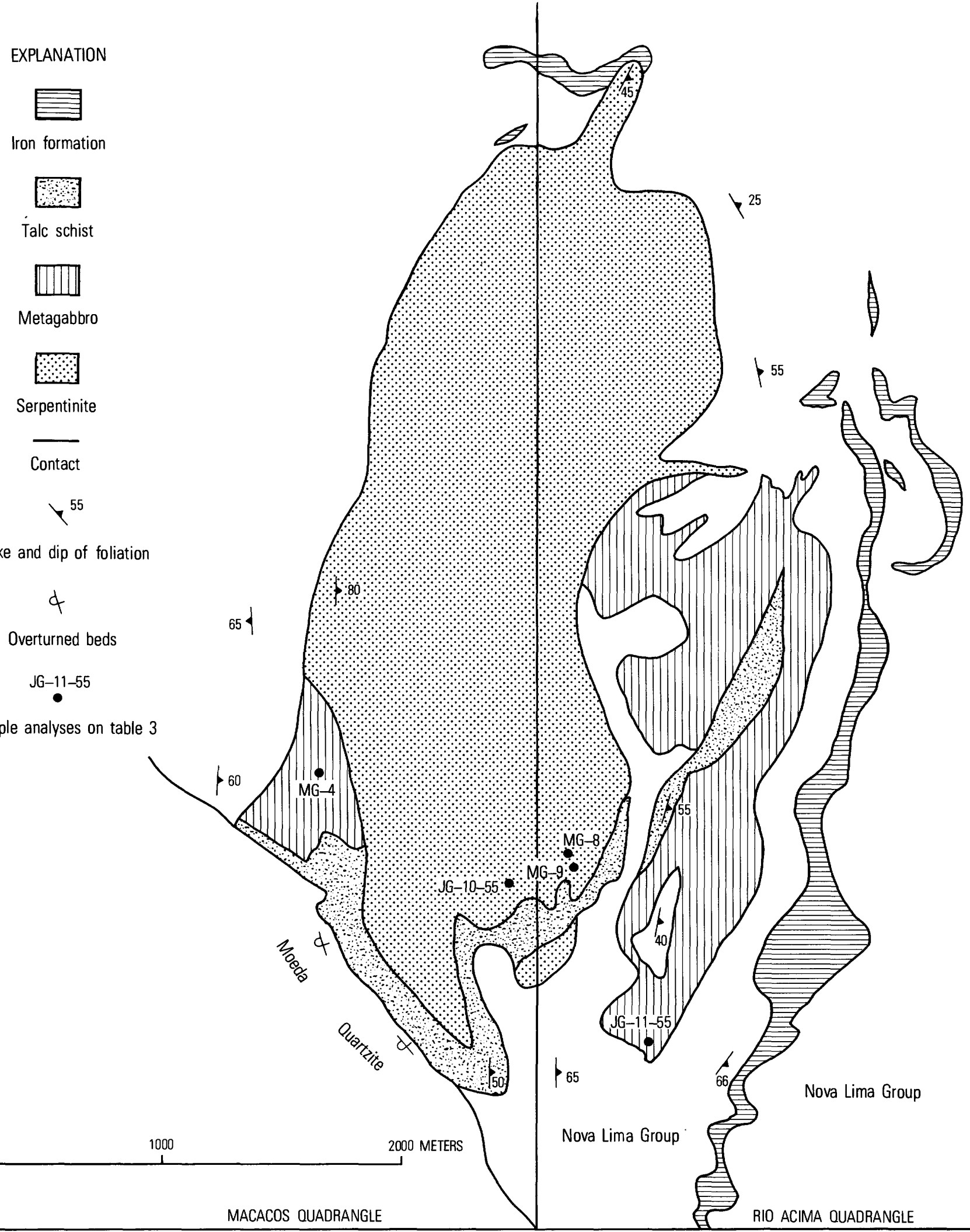

FIGURE 8.-Geologic map showing distribution of ultramafic and mafic rocks in the Rio Acima and Macacos quadrangles. Modified from Gair (1962) and Pomerene (1964). 
TABLE 3.-Chemical analyses and normative minerals from gabbro and ultramafic rocks, Quadrilátero Ferrifero [All samples from Rio Acima and Macacos quadrangles. Samples JG-11-55 and JG-10-55 from Herz (1970, p. B19); other samples, this report. Chemical analyses are rapid-rock analyses using method of Shapiro and Brannock (1956). Cr and $\mathrm{Ni}$ by atomic-absorption spectroscopy]

\begin{tabular}{|c|c|c|c|c|c|}
\hline \multirow{2}{*}{ Sample } & \multicolumn{2}{|c|}{ Gabbro } & \multirow{2}{*}{$\begin{array}{c}\text { Pyroxenite } \\
\text { JG-10-55 }\end{array}$} & \multicolumn{2}{|c|}{ Peridotite } \\
\hline & JG-11-55 & MG-4 & & MG-8 & MG-9 \\
\hline \multicolumn{6}{|c|}{ Chemical analyses (weight percent; $\mathrm{Cr}$ and $\mathrm{Ni}$ in $\mathrm{ppm}$ ) } \\
\hline $\begin{array}{l}\mathrm{SiO}_{2} \\
\mathrm{Al}_{2} \mathrm{O}_{3} \\
\mathrm{Fe}_{2} \mathrm{O}_{3} \\
\mathrm{FeO} \\
\mathrm{MnO} \\
\mathrm{MgO} \\
\mathrm{CaO} \\
\mathrm{Na}_{2} \mathrm{O} \\
\mathrm{K}_{2} \mathrm{O}\end{array}$ & $\begin{array}{l}50.6 \\
15.5 \\
1.9 \\
8.8 \\
.09 \\
7.9 \\
9.3 \\
2.8 \\
.48 \\
.41 \\
.08 \\
2.8 \\
<.05 \\
\end{array}$ & $\begin{array}{l}54.8 \\
14.3 \\
1.1 \\
8.0 \\
.12 \\
6.9 \\
7.5 \\
4.4 \\
.31 \\
.43 \\
.10 \\
1.82 \\
.03\end{array}$ & $\begin{array}{c}51.8 \\
3.4 \\
2.2 \\
5.0 \\
.16 \\
28.1 \\
1.2 \\
.04 \\
.02 \\
.10 \\
.04 \\
7.6 \\
.07\end{array}$ & $\begin{array}{c}41.9 \\
1.1 \\
1.9 \\
5.5 \\
.18 \\
36.5 \\
.02 \\
.02 \\
.10 \\
.05 \\
.05 \\
11.26 \\
.03 \\
\end{array}$ & $\begin{array}{c}43.6 \\
1.7 \\
3.2 \\
1.3 \\
.04 \\
40.7 \\
.00 \\
.01 \\
.00 \\
.05 \\
.04 \\
8.88 \\
.02 \\
\end{array}$ \\
\hline Total & 101 & 100 & 100 & 99 & 100 \\
\hline $\mathrm{Nr}-\mathrm{Ni}$ & $\begin{array}{l}10 \\
30\end{array}$ & $\begin{array}{l}<20 \\
220\end{array}$ & $\begin{array}{r}1,000 \\
300\end{array}$ & $\begin{array}{l}6,800 \\
1,600\end{array}$ & $\begin{array}{l}8,000 \\
1,800 \\
\end{array}$ \\
\hline \multicolumn{6}{|c|}{ Normative minerals (mol. percent) } \\
\hline $\begin{array}{l}\text { Q } \\
\text { Or } \\
\text { Ab } \\
\text { C } \\
\text { Di } \\
\text { Hy } \\
\text { O1 } \\
\text { Ap } \\
\text { II } \\
\text { Mt } \\
\text { Hm }\end{array}$ & \begin{tabular}{r}
-2.6 \\
23.4 \\
26.3 \\
\hdashline 16.0 \\
23.9 \\
5.4 \\
.2 \\
.7 \\
1.5
\end{tabular} & $\begin{array}{r}-1 . \overline{1} \\
36.5 \\
16.9 \\
16 . \overline{-} \\
26.4 \\
.3 \\
.4 \\
.7 \\
.9\end{array}$ & \begin{tabular}{r}
3.8 \\
.1 \\
.3 \\
4.8 \\
.7 \\
\hdashline 88.5 \\
.1 \\
.1 \\
1.6 \\
-0
\end{tabular} & $\begin{array}{r}.5 \\
.1 \\
.6 \\
4.7 \\
49.5 \\
.1 \\
.1 \\
1.4 \\
-1 .-\end{array}$ & $\begin{array}{r}.6 \\
.9 \\
49.3 \\
49.0 \\
0.1 \\
2.0 \\
.1\end{array}$ \\
\hline
\end{tabular}

either dunite or orthopyroxenite. "Bastite textures" suggesting serpentinized orthopyroxene are present in some rocks and make up the greater part of those samples. Chemical analyses of three ultramafic rocks (table 3) confirm these observations.

Sample JG-10-55 is an orthopyroxenite, normative orthopyroxene making up nearly 80 percent of the sample. The chromium content of $1,000 \mathrm{ppm}$ is typical of ultramafic mantle-derived rocks, and the somewhat low nickel content of $300 \mathrm{ppm}$ is in accord with a low modal abundance of olivine in the original rocks.

The metagabbro consists of massive medium- to coarse-grained rocks, which are completely fractured and are penetrated by numerous small veins of altered plagioclase. These rocks consist of hornblende and plagioclase altered to actinolite, albite, clinozoisite, zoisite, sphene, quartz, and carbonate. The grain size of the gabbro is erratic and changes abruptly within even a single outcrop. Chemical analyses of two samples of metagabbros given in table 3 are similar to low-potassium tholeiite basalt containing minor olivine and considerable orthopyroxene in the norm.
Structural relationships between serpentinite and metagabbro are not clear because of very poor outcrops and extensive shearing in the southern part of the area, which has produced talc schists within both serpentinite and metagabbro. In addition, structural relationships with the surrounding Nova Lima rocks are not clear. However, the parallel contacts of gabbro with structurally overlying Nova Lima metavolcanic rocks, which contain interlayered carbonate iron formation, on the east side of the complex shown in figure 8 , suggest the possibility that a stratigraphic sequence from serpentinite to gabbro to metavolcanic rock (containing intercalated carbonate iron formation) may be present within this area. No granitoid rocks are exposed near the ultramafic-mafic complex. Along the southwest margin, the complex lies unconformably beneath quartz-rich rocks of the Minas Series.

Occurrence of ultramafic rocks altered to serpentinite steatite, and talc schists have been described and mapped by Guild (1957) in the Congonhas district, an area famous in Brazil for the production of ornamental stone, statuary, and pottery from steatite. All ultramafic rocks are completely altered to 
antigorite and talc and minor carbonate and magnetite. No gabbro is associated with the ultramafic rocks, but the ultramafic rocks are overlain by greenschists correlated with the metavolcanic rocks of the Nova Lima Group. The greenschists include quartz-muscovite plagioclase-biotite schists retrograded to chlorite and carbonate assemblages and more mafic rocks containing quartz-zoisite-hornblende; both rocks probably were derived from volcanic tuff or reworked pyroclastic rocks.

The ultramafic-greenschist assemblage is underlain by granodiorite, which is massive near the center of the exposed area. It is more sheared and foliated as the contacts with the ultramafic rocks and greenschists are approached. Guild (1957) considered that the greenschists were intruded by an ultramafic magma, forming a thick sill. The sill served to localize a later postorogenic intrusion of granodiorite that contained fragments of the older rocks as xenoliths within the granodiorite.

Most additional occurrences of ultramafic "sills" in the Quadrilátero Ferrifero are at or near the contact of the Nova Lima Group and granitic gneiss and are exposed on the flanks of the geiss domes. These occurrences include outcrops on the eastern flank of the Bonfim dome on the road to Piedade do Parapeba, on the eastern flank of the Bação dome, and on the western flank of the Caeté dome (fig. 2).

Ultramafic rocks at all the above localities crop out in long relatively thin bodies virtually conformable to the foliation of the rocks of the Nova Lima Group. These bodies are either at the contact of the Nova Lima with the granitoid rocks or are within a few hundred meters of that contact. The ultramafic rocks here are also composed of antigorite-talc-magnetite and minor carbonate. At several localities, the rocks are nearly monomineralic talc. On the Piedade do Parapeba road at the contact with the gneisses of the Bonfim dome, the contact of the ultramafic rocks with the overlying phyllite of the Nova Lima Group is marked by a zone of "blackwall" alteration. Here, the ultramafic rocks have the assemblage antigorite-magnetite and are separated from the phyllite by an inner rind of talc-carbonate and an outer rind of chlorite, similar to metasomatic alterations of serpentinite described by Chidester (1962) in Vermont. Thin dikes or sills of foliated mafic rock composed of coarse-grained hornblende, epidote, chlorite, tourmaline, and quartz are common in the area along the contact with the phyllite. Extreme weathering and rugged terrain make it difficult to determine the extent of ultramafic rocks in this area; however, the contact with the mylonitic granitoid rock of the Bonfim dome is easily traced.
At Santa Barbara, about $60 \mathrm{~km}$ east of Belo Horizonte, a "greenstone sequence" including antigorite, antigorite-talc, and antigorite-tremolite assemblages forms a long sill-like mass between the Nova Lima Group and the granitoid basement (Maxwell, 1972; Simmons, 1968b). Southward toward the Serra do Caraça, the structural relationships become more compilcated, and the compilation map of Dorr (1969) in this area provides no unique structural interpretation. The "greenstone sequence" of Maxwell (1972) extends in a broad arc to the east and southeast on the eastern flank of the Serra do Caraça.

In the Itabira district, about $80 \mathrm{~km}$ northeast of Belo Horizonte, rocks of the Nova Lima Group crop out between the granitoid terrane and the iron formations of the Minas Series. The structure of this famous iron-producing region is that of a tight syncline, which has undergone at least two periods of deformation (Dorr and Barbosa, 1963). Here, the lower contacts of the Nova Lima Group are also marked by extensive but irregular masses of antigorite and antigorite-talc serpentinites as well as by small bodies of amphibolite, which Dorr and Barbosa (1963) believe to have been derived from gabbro. Chromitite containing about 45 volume percent chromite was collected from this district (Dorr and Barbosa, 1963, p. 35) ; however, in all other localities, chromite is present only in very minor amounts.

Most workers in the Quadrilátero Ferrifero have believed that the base of the Rio das Velhas Series is not exposed and that the sill-like masses of ultramafic rocks represent intrusions during an early period of igneous activity in the area (Dorr, 1969). We, however, depart from the interpretation on the basis of the following observations: (1) Intrusion of sills of highly refractory rocks such as orthopyroxenite, dunite, and chromitite is unlikely to have taken place except at exceedingly high temperatures. No contact metamorphism has been observed around any of these bodies. (2) The ultramafic rocks generally are found at or near the lowest exposed section of a rock sequence containing flysch-type metasedimentary rocks as well as metavolcanic rocks. Such an association is suggestive of a disrupted ophiolite at the base of a deep marine sequence of rocks. (3) The ultramafic rocks are always at or near the contact between the Nova Lima Group and granitoid rocks, except possibly in the Rio Acima area. The contact is always a zone of profound shearing and cataclasis, suggesting a major thrust zone. From the above three relations, it seems more reasonable to us to interpret the Rio das Velhas 
Series, including broken ultramafic rocks of uppermantle derivation, as representing oceanic lithosphere that has been thrust over an ancient granitic cratonic massif.

\section{CONCLUSION}

In this paper, we interpret the older metasedimentary and metavolcanic rocks of the Quadrilátero Ferrifero as being in thrust contact with a granitoid terrane, which may be a part of the São Francisco craton. Ultramafic and related rocks previously thought to be intrusive into the Nova Lima Group are considered to be dismembered parts of an ophiolite sequence mixed within flyschoid rocks of that group. These rocks were thrust, with the rocks of the Rio das Velhas Series, onto the granitoid craton. After deposition of the Minas Series, and probably the Itacolomi Series, the granitoid craton was deformed into gneiss domes, the process being attended by severe folding of the metasedimentary-metavolcanic cover.

Our most important observation in this study is that the Quadrilátero Ferrifero contains remnants of an allochthon containing ophiolitic material obducted onto a cratonic margin during Archean time. Rubidium-strontium age determinations on muscovite from the Nova Lima Group on the flank of the Bação gneiss dome gave an age of 2,790 m.y., and muscovite from within the dome gave an age of 2,675 m.y. (Herz, 1970). These dates are substantially the same, are obviously from metamorphic. minerals, and therefore must represent a time of metamorphism for both rocks. Thus, the Nova Lima must have been emplaced on the granitic rocks of the Bação dome prior to 2.6 or 2.7 b.y. These dates also give a minimum age for the deposition of the Rio das Velhas Series.

The considerable age of the Nova Lima rocks and their relationship to a possible plate-tectonic event prior to 2.6 b.y. suggests that at least some rigidity of lithospheric rocks could have been obtained by that time. At least in this region, the Permabile Phase of Burke and Dewey (1973) would have ended at some earlier time. The dominant mode of tectonics envisaged is the obduction of a large oceanic section onto a craton; therefore, this region is not an example of intercratonic block tectonics but is more analogous to Phanerozoic tectonics, which may involve the large-scale transport of oceanic lithosphere onto continental margins (Coleman, 1977).

The direction of thrusting of the obducted plate can only be speculative, but the plate may have come from the southeast. This conclusion is based on recent sedimentological studies of the Moeda Formation (D. A. Lindsay, written commun., 1975), which found that the ocean was to the south and east during early Minas time. We have no proof, however, that the older Rio das Velhas Series ocean was in that direction.

Almost certainly, the Rio das Velhas Series ocean is completely closed; any intracratonic suture is cryptic and may be within the vast terrane of granitoid rocks and gneisses between the Quadrilátero and the Atlantic Ocean. A likely place to look for remanents of autochthonous Rio das Velhas rocks, in our opinion, would be in the area of the contact of the multiply deformed granitoid terrane characteristic of the area east of the Quadrilátero and the homogenized granulite terrane farther east that passes from São Paulo through southern Minas Gerais to Espirito Santo.

\section{REFERENCES CITED}

Aldrich, L. T., Hart, S. R., Tilton, G. R., Davis, G. L., Rama, S. N. I., Steiger, R., Richards, J. R., and Gerken, J. S., 1964, Isotope geology: Carnegie Inst. Washington Yearbook $63,1963-64$, p. 331-339.

Almeida, F. F. M. de, Amaral, G., Cordani, U. G., and Kawashita, K., 1973, The Precambrian evolution of the South American cratonic margin south of the Amazon River, in Nairn, A. E. M., and Stehli, F. G., eds., The ocean's basin and margins: New York, Plenum Press, v. 1, p. 411-466.

Anhaeusser, C. R., Mason, Robert, Viljoen, M. J., and Viljoen, R. P., 1969, A reappraisal of some aspeets of Precambrian shield geology: Geol. Soc. America Bull., v. 80 , no. 11, p. 2175-2200.

Burke, Kevin, and Dewey, J. F., 1973, An outline of Precambrian plate development, in Tarlin, D. H., and Runcorn, S. K., eds., Implications of continental drift to the earth sciences: London and New York, Academic Press, v. 2 , pt. 10 , p. $1035-1045$.

Chidester, A. H., 1962, Petrology and geochemistry of selected talc-bearing ultramafic rocks and adjacent country rocks in north-central Vermont: U.S. Geol. Survey Prof. Paper 345, 207 p.

Coleman, R. C., 1977, Ophiolites: Berlin, Springer-Verlag, $229 \mathrm{p}$.

Coward, M. P., James, P. R., and Wright, L., 1976, Northern margin of the Limpopo mobile belt, southern Africa: Geol. Soc. America Bull., v. 87, no. 4, p. 601-611.

Dorr, J. V. N., 2d, 1969, Physiographic, stratigraphic, and structural development of the Quadrilátero Ferrífero, Minas Gerais, Brazil: U.S. Geol. Survey Prof. Paper 641-A, $110 \mathrm{p}$.

Dorr, J. V. N., 2d, and Barbosa, A. L. M., 1963, Geology and ore deposits of the Itabira district, Minas Gerais, Brazil: U.S. Geol. Survey Prof. Paper 341-C, 110 p. 
Dorr, J. V. N., 2d, Gair, J. E., Pomerene, J. B., and Rynearson, G. A., 1957, Revisão da estratigrafia pre-Cambriana do Quadrilátero Ferrífero: Brasil Dept. Nac. Produção Mineral, Div. Fomento Produção Mineral, Avulso 81, $31 \mathrm{p}$.

Eskola, P. E., 1949, The problem of mantled gneiss domes: Geol. Soc. London Quart. Jour., v. 104, pt. 4, no. 416, p. 461-476.

Ferreira, E. O., 1971, Mapa tectonica do Brasil, escala 1:5,000,000 [Tectonic map of Brazil, scale 1:5,000,000]: Rio de Janeiro, Brazil Dept. Nac. Prod. Mineral.

- 1972, Carta tectonica do Brasil; Noticia explicativaTectonic map of Brazil; explanatory note: Brazil Dept. Nac. Prod. Mineral, Bol. 1, 19 p. (Portuguese), 14 p. (English).

Fleischer, Ronald, and Routhier, Pierre, 1973, The "consanguineous" origin of a tourmaline-bearing gold deposit-Passagem de Mariana (Brazil): Econ. Geology, v. 68 , no. 1, p. $11-22$.

Fletcher, R. C., 1972, Application of a mathematical model to the emplacement of mantled gneiss domes: Am. Jour. Sci., v. 272, no. 3, p. 197-216.

Gair, J. E., 1962, Geology and ore deposits of the Nova Lima and Rio Acima quadrangles, Minas Gerais, Brazil: U.S. Geol. Survey Prof. Paper 341-A, 67 p.

Goodwin, A. M., 1973, Plate tectonics and evolution of Precambrian crust, in Tarlin, D. H., and Runcorn, S. K., eds., Implications of continental drift to the earth sciences: London and New York, Academic Press, v. 2, pt. 10, p. 1047-1069.

Guild, P. W., 1957, Geology and mineral resources of the Congonhas district, Minas Gerais, Brazil: U.S. Geol. Survey Prof. Paper 290, 90 p.

Harder, E. C., and Chamberlin, R. T., 1915, The geology of central Minas Gerais, Brazil: Jour. Geology, v. 23, no. 4, p. $341-378$.

Herz, Norman, 1970, Gneissic and igneous rocks of the Quadrilátero Ferrífero, Minas Gerais, Brazil: U.S. Geol. Survey Prof. Paper 641-B, 58 p.

1978, Metamorphic rocks of the Quadrilátero Ferrífero, Minas Gerais, Brazil: U.S. Geol. Survey Prof. Paper 641-C, $81 \mathrm{p}$.

Herz, Norman, Hurley, P. M., Pinson, W. H., and Fairbairn, H. W., 1961, Age measurements from a part of the Brazilian shield: Geol. Soc. America Bull., v. 72, no. 7, p. 1111-1120.

Johnson, R. F., 1962, Geology and ore deposits of the Cachoeira do Campo, Dom Bosco, and Ouro Branco quadrangles, Minas Gerais, Brazil: U.S. Geol. Survey Prof. Paper 341-B, 39 p.
Maxwell, C. H., 1972, Geology and ore deposits of the Alegria district, Minas Gerais, Brazil: U.S. Geol. Survey Prof. Paper 341-J, 72 p.

Moore, S. L., 1969, Geology and ore deposits of the Antônio dos Santos, Gongo Sôco, and Conceição do Rio Acima quadrangles, Minas Gerais, Brazil: U.S. Geol. Survey Prof. Paper 341-I, 50 p.

Pearson, D. E., and Lewry, J. F., 1974, Large-scale fold interference structures in the Mudjatik River area of northern Saskatchewan: Canadian Jour. Earth Sci., v. 11 , no. 5, p. 619-634.

Pettijohn, F. J., 1957, Sedimentary rocks (2d ed.): New York, Harper \& Bros., 718 p.

Pinson, W. H., Jr., Whitemore, D. O., Fairbairn, H. W., and Hurley, P. M., 1967, Rb/Sr whole rock ages of rocks near Sete Logoas, Minas Gerais, Brazil, in Variation in isotopic abundances of strontium, calcium, argon, and related topics-15th Annual Progress Report: Cambridge, Massachusetts Inst. Technology, Dept. Geology and Geophysics, p. 37-39.

Pomerene, J. B., 1964, Geology and ore deposits of the Belo Horizonte, Ibirité and Macacos quadrangles, Minas Gerais, Brazil: U.S. Geol. Survey Prof. Paper 341-D, $84 \mathrm{p}$.

Ramsay, J. G., 1967, Folding and fracturing of rocks: New York, McGraw-Hill, 568 p.

Reeves, R. G., 1966, Geology and mineral resources of the Monlevade and Rio Piracicaba quadrangles, Minas Gerais, Brazil: U.S. Geol. Survey Prof. Paper 341-E, $58 \mathrm{p}$.

Shapiro, Leonard, and Brannock, W. W., 1965, Rapid analysis of silicate, carbonate, and phosphate rocks: U.S. Geol. Survey Bull. 1144-A, 56 p.

Simmons, G. C., 1968a, Geology and iron deposits of the western Serra do Curral, Minas Gerais, Brazil: U.S. Geol. Survey Prof. Paper 341-G, 57 p.

1968b, Geology and mineral resources of the Barão de Cocais area, Minas Gerais, Brazil: U.S. Geol. Survey Prof. Paper 341-H, 46 p.

Thompson, J. B., Jr., Robinson, Peter, Clifford, T. H., and Trask, N. J., 1968, Nappes and gneiss domes in westcentral New England, in Zen, E-an, and others, eds., Studies of Appalachian geology-northern and maritime: New York, Interscience Publishers, p. 203-218.

U.S. Geological Survey, 1973, Geological Survey research 1973: U.S. Geol. Survey Prof. Paper 850, 366 p.

Wallace, R. M., 1965, Geology and mineral resources of the Pico de Itabirito district, Minas Gerais, Brazil: U.S. Geol. Survey Prof. Paper 341-F, 68 p. 